\title{
Developing climate-responsive cities: exploring the environmental role of interstitial spaces of Santiago de Chile
}

\author{
Cristian Silva
}

Abstract: Drawing upon a range of writing on suburbanisation and urban sprawl, this paper outlines an approach to the analysis of interstitial spaces of urban sprawl. Such spaces are the outlying geography of metropolitan regions existing in-between developed or urbanised areas. As such, they constitute an eclectic mix of open spaces, natural areas, obsolete infrastructures, geographical restrictions, farming land, etc, that alternatively contribute to the city's environmental and functional performance. Despite being identified in the literature, there has been little recognition of interstitial spaces as part of the environmental sustainability of urban systems, and how they support cities in improving their resilience and adaptation capacities. Using the case of Santiago de Chile, this paper highlights an environmental approach to studying the interstices and the need to examine such spaces at different scales linked to their respective environmental potentials.

Keywords: Interstitial spaces, urban sprawl, climate change, urban sustainability, Santiago de Chile.

Note on the author: Dr Cristian Silva has a PhD in Urban Studies and is Lecturer in Spatial Planning at Queen's University Belfast. His research is centred on the explorations of contemporary patterns of urban growth and change, urban sprawl, and (post)suburbanisation, with a particular emphasis on the role of 'interstitial spaces' in restructuring city-regions.

\section{Recent relevant publications:}

Silva, C. (2020), 'The Rural Lands of Urban Sprawl: Institutional Changes and Suburban Rurality in

Santiago de Chile', Asian Geographer, 37(2): 117-44. https://doi.org/10.1080/10225706.2019.1701505

Silva, C. (2019), 'The Interstitial Spaces of Urban Sprawl: Unpacking the Marginal Suburban

Geography of Santiago de Chile', in N.H.D. Geraghty \& A.L. Massidda (eds) Creative Spaces:

Urban Culture and Marginality in Latin America (London, Institute of Latin American Studies,

University College London), 55-84

Phelps, N.A. \& Silva, C. (2017), 'Mind the Gaps! A Research Agenda for Urban Interstices', Urban

Studies, 55(6): 1203-22. https://doi.org/10.1177/0042098017732714

https://orcid.org/0000-0001-9575-5737

c.silva@qub.ac.uk

(C) The author(s) 2021. This is an open access article licensed under a

Creative Commons Attribution-NonCommercial-NoDerivs 4.0 Unported License 


\section{Introduction}

Recent decades have witnessed debates within urban studies regarding the impacts of extended suburbanisation and what this implies for the nature of cities, the countryside, and the sustainability of entire regions (Keil 2017). These debates have been grounded in various conflicting theoretical approaches in which differing positions have been developed, including the ideological meanings of extended suburbanisation and sprawling growth (Phelps 2012). On the one hand, supporters of urban sprawl highlight the importance of extending suburbia as a way of tackling housing shortages whilst responding to increasing population and employment growth (Rice 2010). On the other hand, anti-sprawl narratives raise extensively documented issues of economic, social, and environmental impacts (Johnson 2001, Romero \& Órdenes 2004). If we consider that nearly 80 per cent of global primary energy is consumed in cities and 60 per cent of the world's overall greenhouse emission is produced by cities (Gargiulo \& Russo 2017), we would also need to clarify that this impact originates from extended suburbia as more than 85 per cent of urban dwellers reside in suburban areas (Keil 2017). In these contexts, spatial fragmentation and the extensive geographical scale of urban sprawl shape the city as 'no longer defined as an individualised centre nor does it correspond to a harmonious and coherent group of elements' (Sousa 2009: 61). Instead, the resulting sprawling geography is composed of a mix of built-up areas and a diverse spectrum of interstitial spaces that lie between developments that make cities physically discontinuous, spatially porous, and environmentally diverse.

These urban interstices, however, have not received enough attention in the planning literature - often focused on built-up space - even when they are intrinsic components of fragmented suburbanisation. Although calculated to be substantial (Dubeaux \& Sabot 2018), the interstitial spaces are less examined due to their apparent condition as empty, undeveloped, under-developed, leftover, vacant, inert, or simply pending spaces for further urbanisation. Nothing could be further from the truth, however, as "when one penetrates the system of interstitial spaces and starts to explore it, one realises that what has been called "empty" is not so empty after all. Instead, it contains a wide range of uses' (Sousa 2009: 66). Aside from their functional potentials, it has also been argued that interstitial spaces are the source of a substantial proportion of wealth that contributes to the organisation of society (Rickards et al. 2016, Zhang \& Grydehøj 2020). It has been demonstrated that, 'despite a select group of urban centres generating a disproportionate amount of global economic output, significant attention is being devoted to the impact of urban-economic processes on interstitial spaces lying between metropolitan areas' (Harrison \& Heley 2015: 1113). This also demonstrates the scalar significance of interstitial spaces - that ranges from the liminal space between two buildings up to the rural space between - while opening 
questions 'concerning how rural spaces are conceptualised, governed and represented' (1113). Interstitial spaces embrace both the 'rural' and the inner land of cities, including industrial areas, farming spaces, mining zones, natural reserves, landfill, brownfield sites, abandoned areas, conurbation spaces, desert land, mountains, rivers and large bodies of water, as well as other geographical restrictions with yet unexplored ecological contents (Gandy 2011). All of them constitute an interstitial geography that is often marginalised (and/or excluded) from studies of cities and their built-up dimension. This lack of attention becomes critical when raising questions around the environmental potential of interstitial spaces, how they contribute to the urban character of cities, and how they improve urban resilience under pressing issues of environmental pollution and climate change (French et al. 2019).

This article examines this environmental role of interstitial spaces in developing climate-responsive cities through combining morphological and qualitative analysis. The discussion is empirically based on the capital city of Chile-Santiago-from which three types of interstices are selected to analyse their spatial and environmental significance: a) a cluster of small-scale suburban farming lands, b) a large-scale cluster of mining sites surrounded by consolidated neighbourhoods, and c) the southern conurbation space defined by regional transport corridors linked to regional demands. The first case introduces the values of suburban rurality and open space in securing the social and environmental sustainability of deprived peripheries. The second case illustrates how a highly polluted mining site can become a valuable three-dimensional landscape that provides public space and stormwater collection within impervious suburbia. The third case unveils the potential of conurbation zones as hybrid spaces in which regional, urban, and rural systems enable adaptation strategies and climateresponsive peripheries. These interstitial spaces are multifaceted elements within the homogenous suburban space of Santiago, and present a clear potential of becoming valuable environmental assets for the whole metropolitan space. Located in the south of Santiago - the most important axis for suburban expansion - they are surrounded by large concentrations of social housing developments, regional infrastructure, agriculturally fertile land, and a system of microclimates that stabilise the metropolitan temperature and improve the city's resilience. However, these interstitial spaces fall into simplistic categorisations as 'empty sites' that can be further urbanised. These selected interstices are used as a basis for abstraction and generalisation, given that the analysis has salience to the vast majority of cities.

The research in which this paper is based involved mapping, semi-structured interviews, and spatial analysis of the selected interstices identified as strategic by policymakers. In the first section, debates on urban sprawl and interstitial spaces are expanded. This highlights the role of interstices in the suburbanisation process and their spatial significance from an environmental perspective. Then, the three selected 
cases from Santiago are described and analysed to provide insights into their environmental properties and how they can contribute to developing a climateresponsive city. The conclusions underline the environmental values of interstitial spaces which render cities more resilient and environmentally sustainable, and the need for adapting planning to the challenges suggested by the interstitial spaces while integrating insights from the different disciplines concerned with the built environment.

\section{Interstitial spaces and the urban condition}

Since their origins, cities have been spatially composed of different built-up areas and interstitial spaces that lie between developments. Pieces of countryside, farming land, undeveloped areas and open tracts of different sorts, derelict land, abandoned infrastructure, urban landfill, large public spaces, geographic accidents, etc, configure an eclectic mix of in-between land that has been addressed by the literature in a very fragmentary way. Indeed 'urban interstitial spaces are often defined as anti-space, latent space, or dormant spaces' (Hugo \& du Plessis 2020: 591), while they are also described as vacant land (Ige \& Atanda 2013), urban voids, undeveloped (or underdeveloped) areas, open tracts, derelict land, leftover spaces, unbuilt land, terrain vagues (Mariani \& Barron 2013, Solá-Morales 2002), wildscapes (Jorgensen \& Keenan 2012), non-urbanised areas (La Greca et al. 2011), or inter-fragmentary spaces (Vidal 2002) inter alia. These spaces, however, are far from being empty, abandoned, or derelict; rather they are spatial gaps in the urban fabric regarding their surroundings. In that sense, a low-density neighbourhood situated within a highly densified area is also interstitial. This situation is observed in various cities in China and Hong Kong where low-density neighbourhoods are surrounded by high-rise buildings; an interstitial density that allows further growth and adaptation to contingent issues of housing shortage or climate change (Lu et al. 2017). Considering this variety-and a means of unifying the understanding of such spaces - the term 'interstitial space' is used in this paper to generically denote any kind of in-between space that emerges as 'a gap' that is not clearly coalesced into the city's fabric. As such, the interstices contribute to the city's porosity and the production of available space for further adaptation capacities and change.

Interstitial spaces have become significant and may be on the increase in the context of urban shrinkage (Dubeaux \& Sabot 2018). They represent a considerable proportion of the urban hinterland in some Latin American cities. The vacant land of Rio de Janeiro alone defines around 44 per cent of the total municipal area, while it is 21.7 per cent in Quito. San Salvador shows 4.65 per cent vacant sites, although the 
authorities also count areas of informal occupation that are included in the list to be demolished, reaching a total of 40 per cent of whole urban space. In Buenos Aires, vacant land represents 32 per cent of the metropolitan area (Clichevsky 2007), while in Santiago de Chile it is close to 19 per cent (Cámara Chilena de la Construction 2012). In the case of American cities an average closer to 15 per cent has been reported (ibid). These percentages are mainly concentrated in suburban, peri-urban, and fringebelts areas - all constitutive of urban sprawl contexts - which poses important questions regarding the unsustainable character of sprawling suburbanisation as it nevertheless represents a major source of infrastructural and environmental assets (Gavrilidis et al. 2019).

In this vein, focusing on interstitial spaces within processes of sprawling suburbanisation becomes relevant, considering that urban sprawl is determined by increasing rates of land fragmentation (Inostroza et al. 2013). More importantlyand against most orthodoxies - urban sprawl has become the home of most of the worldwide population. Although demographic projections indicate that most people live in urban areas, 'the majority of the world's population is actually suburban in location' (Phelps 2021: 345). This makes urban sprawl more significant in terms of how interstitial spaces can determine the potential sustainability of urban systems. This role can indeed go beyond established narratives of retrofitting, to implementing climate change adaptation and mitigation strategies. Thus, leaving interstices unbuilt (or less built), empty, or simply opened to wild urban nature (Gandy 2011, 2013) suggests alternative modes of production of the space as a synonym for built-up. Politics around the role of interstitial spaces as empty land can indeed counteract the negative connotation of urban sprawl as a 'disorganised urban' (Phelps 2012) as this is mainly associated with what has been built rather than what is left in-between. As Sievert suggests (2003), 'instead of talking dismissively about urban sprawl, we could recognise that there is a fine-grained interpenetration of open space and built form and see the open space as the binding element, with its new creative potential' (49). Thus, the role of interstitial spaces in activating new expressions of urban nature and public space reinforces the character of cities as environmentally diverse and non-continuous environments.

The interstitial spaces also provide space for social interactions and contact with nature at different scales and with different levels of relationality. Urban interstices can separate communities as well as bridge them while acting as intersections, boundaries, and borders (Iossifova 2013). As such, they can be politically mediated to improve the social and environmental resilience of cities while reinforcing their urban character (Kaika 2005). This conceptual reflection has been advanced by Storper and Scott (2016) who dispute the generalisation of cities as 'urban systems' per se and place the role of interstices as key elements of cities. They argue that 'cities' are a very 
specific form of urbanisation that 'formally represent the geographical containers within which contemporary human society unfolds' (1117), while the 'urban' emerges as 'the organic divisions of labour in which social and economic life (that is, the production of goods and services, but also including cultural, religious, and governmental pursuits) is organised and reorganised within networks of specialised but complementary units of human activity' (1116). Notably, these organisations are not exclusively placed in 'the city', but within what the authors coined as 'the urban landnexus' - an ostensibly neutral interstice - which 'corresponds to the essential fabric of intra-urban space' (Scott \& Storper 2014: 8). In this space, there is a partial or total absence of effective mechanisms of collective coordination that define 'numerous kinds of disfunctionalities ranging from infrastructure breakdowns to locational conflicts, and from deteriorating neighbourhoods to environmental pollution' (9). Thus, while the interstices are 'urban' in nature, they cannot necessarily be part of 'the city' as such. Despite this, interstices can contribute to the urban character of cities precisely through their condition as devices that absorb changes, climate adaptation, allow further growth, and improve environmental resilience and other processes that support the city's sustainability (French et al. 2019).

At a wider scale, insights from 'planetary urbanisation' (Brenner \& Schmid 2014) entail that the scale at which interstitial spaces are manifested includes those rural hinterlands between cities and regions. This extensive realm is again not an inert space, but the extension of the urban condition manifested in the city in which 'the urban cannot be plausibly understood as a bounded, enclosed site of social relations that is to be contrasted with nonurban zones or conditions' (750). Koolhaas (2021) also noted that 'the countryside' is a space that affects the resilience and adaptation capacities of cities as currently determined by the size of architectural artifacts, functions, economic processes, technological innovations, and environmental impacts that have no precedents in human history (Koolhaas 2021). Thereby, the rural space between (and beyond) cities emerges as a colossal landscape that is not only infrastructural but also cultural and environmental. Insights from urban political ecology touch on these issues when suggesting that 'urban areas have been exploding relentlessly beyond their boundaries, producing a highly uneven urban fabric that ceaselessly extends its borders across non-urban geographies' (Arboleda 2016: 234). These interstitial spaces between urban agglomerations are indeed the scenarios of some of the most radical environmental alterations and 'alert us to the fact that the metabolic exchanges of matter, energy and capital required to feed the contemporary urban world have been distorted and up-scaled to the point that they have now reached a hypertrophic, global extent' (234).

Interstitial spaces can be manifested at different scales ranging from narrow intra-urban spaces - such as the abandoned space between two buildings - up to 
conurbation zones between two or more city-regions. As such, they influence the way cities respond to environmental changes and, thus, how cities sustain their urban character. Evidently, interstitial spaces offer an alternative analytical point of entry into studies of urbanisation, suburbanisation, and urban sprawl, and call 'for the development of theories of urban politics beyond the city or the urban as a single undifferentiated unit' (Phelps \& Silva 2017: 1219).

\section{The relationality and morphology of interstices}

One aspect that influences the adaptation capacity of interstitial spaces and their integration into the city's dynamics is their relationality. It has been documented that some interstices are more disconnected from the city's fabric while others are fully integrated, even when their property regimes do not allow any form of occupation (Brighenti 2013). At a regional scale, some interstices operate as bridge areas among distant clusters of economic trade (Zhang \& Grydehøj 2020), while others are disconnected from their areas of influence. This is the case of mining activities located between cities that have an environmental impact in surrounding villages and towns (Arboleda 2020). As such, the interstices can be beneficial at large scales of economic exchange while detrimental at scales of proximity. Similarly, interstices defined by heavy infrastructure - such as motorways or railway lines-emerge as physical divisions and restricted areas for nearby communities while their intensive provision of mobility might signal significant economic potential at regional levels (Figure 1).

To understand the relationality of interstices, it is necessary to revise the role of infrastructures and their morphology. Rodrigo Vidal's notion of 'inter-fragmentary space' helps in indicating that 'the urban phenomenon is essentially a permanent tension between fragments' (Vidal 2002: 150): a tension triggered (or supported by) different types of infrastructures and relational mechanisms. According to Vidal, the relationality of the inter-fragmentary space ranges from very narrow infrastructuressuch as a fence between two sites - to a wide range of transport connections between towns. When the inter-fragmentary space becomes functionally autonomous, it becomes 'an interstice'. As such, 'the interstice' is not a mere leftover space but a place of transition and change; an incomplete and pending space with its own temporalities (Vidal 2002). Similarly, Meijers and Burger (2017) identify a transitional interstitial zone around cities named the 'Functional Urban Area' (FUA) wherein different economic and environmental processes occur. The FUA can also be amalgamated with other transitional zones that determine the 'Potential Integration Area' (PIA) (Meijers $\&$ Burger 2017). This relational potential of interstices highlights 'the inseparability 


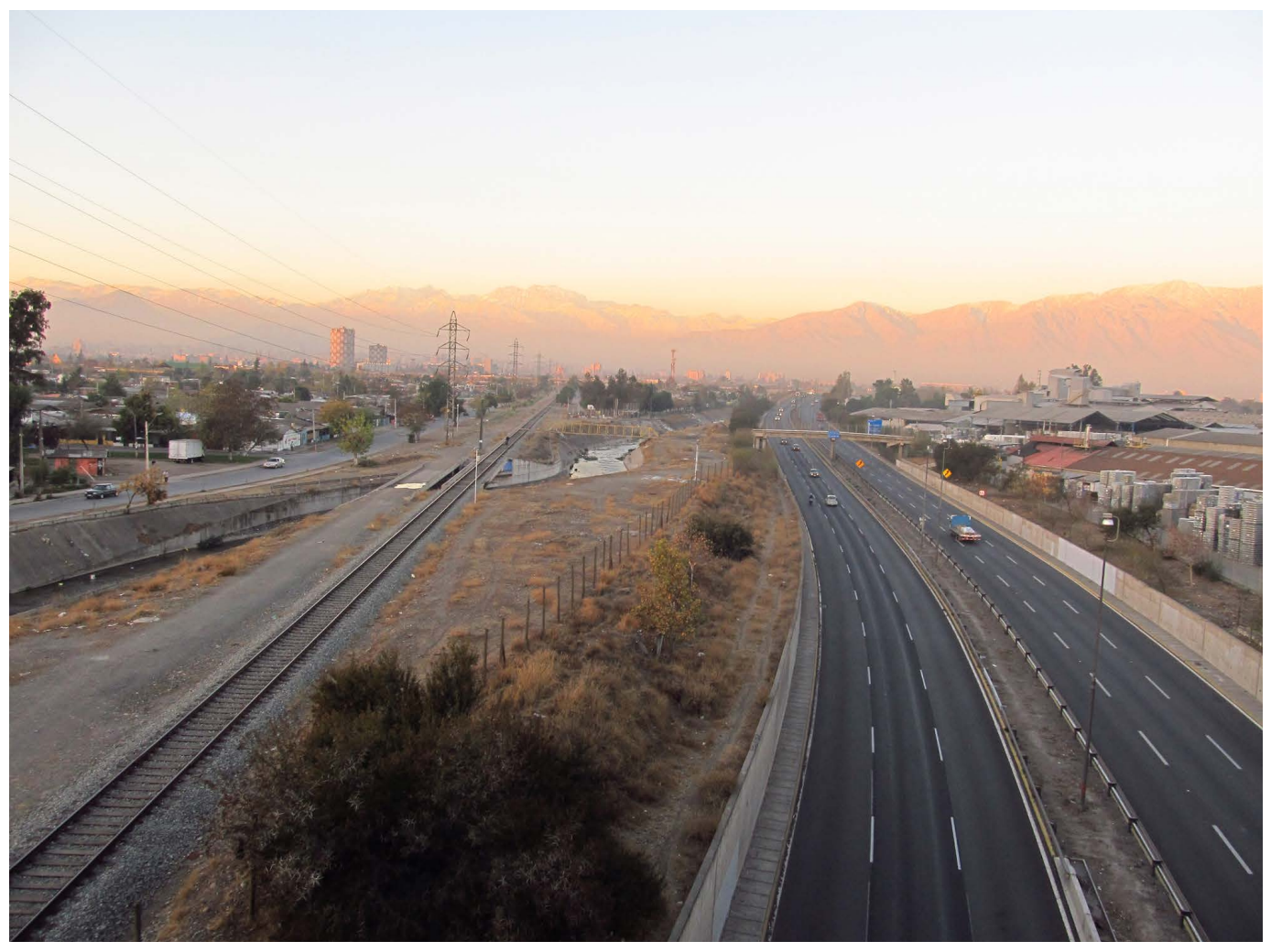

Figure 1. An infrastructural interstice at the boundary of the communes of Cerrilos and Pedro Aguirre Cerda, Santiago de Chile (author's photo, 2014).

of analytical perspectives and normative agendas on urban dynamics as much as the built environment' (Phelps \& Silva 2017: 1219).

In morphological terms, a physically bounded interstitial space-with no infrastructure of connectivity or restricted access - appears less relational regarding those with spatially permeable boundaries. These elements-boundaries and functions - influence the role of interstices as mediators or barriers between surroundings. This could be the case of a military installation, a security buffer, a power plant, an industrial facility, or a non-urbanised island within a system of urbanised archipelagos (Zhang \& Grydehøj 2020). Planning policies felt in the urban fringe belt have also determined the morphological features of interstices. The promulgation of macroscale plans designed to preserve open land - such as the 'Five-Finger Plan' of Copenhagen (Caspersen et al. 2006) or the 'Green-Heart' project in Netherlands (Salet \& Woltjer 2009) - illustrate interstices as planned spaces with a clear morphological pattern that articulate varied social, political, and economic forces as part of 'the urban'. The emergence of suburban interstices in Latin America, however, derives 
from a more liberal approach to land planning (Silva 2019) that defines urbanisation in specific locations and, thus, the interstices are randomly distributed in the city (del Castillo \& Sopla 2018). The competing economic, social, and environmental values adhering to interstitial spaces ensure that some of them-including those attractive to the private sector - remain pending for prodigious periods of economic growth or financial stability (López-Morales et al. 2019). Other factors relate to the emergence of informal settlements mainly fuelled by natural growth and rapid internal and cross-border migration (Sandoval \& Sarmiento 2020). The informal settlements define morphological patterns that clearly contrast with those determined by institutional policies or technical macro-scale plans. These differences in the policy framework that produces interstitiality also determine their transition to become urbanised or remain interstitial. This ambivalent condition (urbanised/non-urbanised) highlights the temporal (and spatial) ruptures in the urban fabric (Sola-Morales, 1995) and explains the random spatial distribution of interstices with an unpredictable morphological pattern. The fact that 'an unintended fringe belt may contribute as much to the legibility of a city as a fringe belt with a planned feature' (Whitehand 2001: 108) confirms both the planned and unplanned morphology of interstitial spaces.

The obsolescence of industrial facilities and functions also determines the morphology of urban interstices. Cities that have entered into economic decline and loss of population - such as Detroit or some 'ghost towns' in China (Batty 2016, Xie et al. 2018) - may indeed show an increase in interstitial spaces (Dubeaux \& Sabot 2018). Here, interstices appear as unused sites resulting from the obsolescence of previously active built-up areas. These spaces become nevertheless significant as they provide accessible land for spontaneous functions, urban nature, and use of open space. Indeed, it has been demonstrated that 'with shrinkage and numerous demolition programs, vacant spaces became very important' (8) considering demographic decline that at least balances the proportion of open space for the remaining population. In extreme situations, the excessive emergence of abandoned sites and infrastructures all over the city can trigger a spiral of population decline associated with crime and squatting. If this process extends beyond what can be controlledwhich is the case of the 'ghost towns' - the emptiness can absorb large urban areas that makes an entire city interstitial (Skidmore 2014). De Solá-Morales' terrain vague characterises these abandoned and obsolete infrastructures as 'vague' in the sense of empty — without activities or functions - and in a clear stage of ruin. These spaces are imprecise, undefined (a 'form of absence'), and without fixed limits or future destinations (de Solá-Morales 2002). The importance of these spaces relates to their significance as pieces of history and collective memory (Gandy 2016), and their environmental functionality to balance water flows and control water streams during extreme rainfall events (Li et al. 2014). 


\section{The environmental flexibility of the interstices}

In 1993, the Dutch architect Rem Koolhaas proposed the term 'nothingness' to elucidate the spatial character of Berlin after World War 2. The city was shaped by different survival of built-up spaces interspersed with urban voids resulting from the destruction of the city. These voids - with no architecture or development of any kind but only ruins - amalgamated the fears of the past with the hopes and optimism of the city's reconstruction. This optimism relied on the authorities' willingness of filling the voids with new urbanisations. However, Koolhaas contested institutional attempts to reknit the damaged urban fabric by filling the voids arguing that any attempt would bury the scars of the city, its recent history, and, most importantly, the still unknown opportunities ahead. The architect expressed this by indicating that 'where there is nothing, everything is possible; where there is architecture, nothing (else) is possible' (Koolhaas, 1995: 199). Alternatively, Koolhaas contended that Berlin is now divided and dispersed, a decentralised city in which the urban voids express Berlin's new character of a dazed, fragmented, and destroyed land with no centre. For Koolhaas, the future of Berlin must precisely operationalise the destruction (or deconstruction) as a mechanism that (re)creates the character of Berlin, and even creates new voids by demolishing dysfunctional parts. This operation would leave space for the wild forest to grow and create a place in which isolated (and somehow hidden/desolate) islands of infrastructure and ruins are dispersed. Koolhaas proposed a city in which the built-up space would float within a large empty space of 'nothingness': the new urban condition for Berlin defined by unplanned and planned interstitial spaces.

Following Koolhaas's imaginaries on Berlin — and the implications of urban voids in the socio-political agenda - the emergence of interstices ostensibly seems to be a matter of intended design as well. Interstices can be planned as flexible spaces for growth, functional fluidity, attraction of wildlife, and improvement of absorption capacities in storm events and other natural disasters (Hugo \& du Plessis 2020). Moreno-Pessoa et al. (2016) argue that it is possible to make some cities more resilient by enhancing the urban porosity determined by the interstices, although other cities can be led to socio-spatial segregation as porosity has different effects in different contexts. The authors indicate that 'what is a challenge in one urban system may become an opportunity in a different system' (48). Therefore, porosity must be carefully analysed before implementation, in regard to specific levels of socio-spatial segregation, exposure to natural disasters, and lack of open spaces. Implementing urban interstices can separate communities, but also facilitate the co-existence of functions and the expansion of services in key locations (Viganò 2013). Interstitial spaces can also operate as public venues in periods of normal functionality, or as 
public shelters in the emergency of an earthquake, flooding, storm events, etc (French et al. 2019). However, it is important to emphasise that the flexibility of interstitial spaces in hosting multiple functions - and their capacity to adapt to and absorb changes - not only relies on its spatial aspects but also on the regulatory constraints imposed by planning regulations. To an extent, undeveloped land represents natural or regulatory constraints that can be unlocked (Dubeaux \& Sabot 2018).

On this basis, the environmental flexibility of interstices still emerges as the primary factor for spatial adaptation considering that planning and policy constraints 'are social or regulatory constructions which can be unmade or are natural features that could be "improved" or "reclaimed" to allow development' (Phelps \& Silva 2017: 1204). This environmental flexibility can be determined by the environmental potentials of interstices, their spatial attributes to absorb change, and their scalar and multifunctional character determined by different land uses, morphologies, and infrastructures of relationality.

\section{The environmental potentials of interstitial spaces}

It has been clarified that less planned interstices give space for the proliferation of urban wildlife; places where different expressions of spontaneous flora and fauna can flourish (Gandy 2011). This includes abandoned buildings, ruins, or unattended facilities that Jorgensen and Keenan (2012) define as 'wildscapes': places where planning forces of control do not operate at all. Similarly, Gandy's notion of 'wastelands' (2013) highlights the values of abandoned, marginalised, and forgotten spaces characterised by exuberant flora and fauna with both aesthetic and ecological benefits. These interstitial landscapes offer an alternative point of entry into scientific exploration of urban wildlife, nature, climate change, mitigation of flooding and extreme rain; 'wastelands' become valuable gears of urban ecosystem services characterised by specific aesthetics, high levels of biodiversity, random expressions of freedom, hints of history, and spatial novelty (Gandy 2013). These interstices become strategic in minimising pollution, improving climate change adaptation capacities, enhancing contact with nature, and improving overall urban quality and human well-being (Savarda et al. 2000). The ecological values of interstices prevent the loss of biodiversity, reduce air and noise pollution, and regulate temperature while diminishing the heat-island affect (Kleerekoper et al. 2012). Considering their varied magnitudes, some of them are big enough to ensure the survival of some flora and fauna while smaller interstices provide space for community projects and improvement in community resilience. There are several examples of abandoned parks recovered by local residents, volunteers, local councils, community groups, and 
non-governmental organisations (NGOs) that are suitable for the implementation of social programmes of urban agriculture, educational activities, domestic animal husbandry, and community engagement (Saunders 2011).

\section{The spatial attributes of interstitial spaces}

An emerging approach for planning the interstices relates to the notion of 'sponge cities' (Jiang et al. 2018). This idea aims to introduce (or preserve) interstices to increase the city's spatial porosity and, thus, improve its capacity to absorb stormwater. In some Chinese cities, pluvial flood disasters have become a regular hydrometeorological phenomenon and are of increasing concern due to their environmental, economic, and social damage (Zevenbergen et al. 2017). For some, these events are caused by climate change (Duan et al. 2016), which is driving a significant overall increase in rainfall across most global regions (You et al. 2011). Although the concept itself still mainly established in the Chinese context, the underlying planning and design principles of creating permeable surfaces, increasing open spaces, and implementing interconnected green corridors that respond to climate events have been implemented in various Latin American cities (Herzog 2016, Pessoa et al. 2016, Vásquez et al. 2016, 2019). Thereby, the general objectives of the 'sponge city' could soon be a transnational concept as it offers substantial ways of restoring the city's capacity to absorb, infiltrate, store, purify, drain, and manage rainwater by replicating natural hydrological cycles.

As such, the introduction of interstitial spaces requires a volumetric planning and design approach-beyond bi-dimensional land-use planning-to embrace the three-dimensional character of water cycles, climate components in which the interstices participate, control over varied streams of air, and underlying irrigation design (Moreno-Pessoa et al. 2016). At an architectonic scale, studies on urban morphology and residential climate have confirmed the importance of implementing interstices in large densified areas of sub-tropical regions - especially during hot and humid summers - as compact building blocks create stagnant air that worsens outdoor urban thermal comfort (Yuan \& Ng 2012). In Hong Kong, for instance, high-rise compact buildings define deep street canyons that create barriers for street ventilation and lack of public open space. Thus, introducing voids 'within' the blocks becomes an opportunity to supply open space for communities (ibid). It has also been argued that porosity can transcend the morphology of buildings to connect with the existing voids of the city (Tadi et al. 2017). As such, both the open space of the city and building voids can be integrated into a continuous network of interstitial spaces that can make a difference in terms of resilience and adaptation capacities to climate change. Reference to urban voids as part of buildings' morphology and the city's volume 
proves the three-dimensional potential of interstices, not solely limited to the ground floor level or bi-dimensional conception of land uses (Gallent \& Shaw 2007).

\section{The multifunctional character of interstitial spaces}

A key aspect of the flexibility of interstitial spaces is their capacity to absorb different functions over time while preserving their original morphology. Studies conducted in Latin America and the Middle East provide enough evidence to illustrate how in some cities the streets become improvised football pitches, while proper football pitches become open spaces for massive events such as music gigs, fairs, celebrations, or temporary markets (Anuar \& Ahmad 2018, Uehara et al. 2018). A similar situation is observed in some European cities in which vacant plots planned for future extensions of infrastructure or services are used for 'pop-up' functions-functions that operate for a short period of time - that sustain the adaptation capacity of the city (Bertino et al. 2019). Other derelict spaces defined by motorways and leftover spaces found in parking lots or neighbourhoods are used as public venues (Endres et al. 2014, Milián Bernal 2020). It is argued that 'informality provides an opportunity for those excluded from formal processes to find presence in the city' (Wall 2011: 155) and, thus, reinforce the social resilience of organised (and eventually subversive) groups. In the US and Mexico, it has been demonstrated that, in the context of decreasing food security, large cities can achieve resilience through local food systems, green infrastructure, and ecosystem services by using their intra-urban interstitial spaces (Hare $\&$ Peña del Valle Isla 2021). Although these inner interstices are often claimed by local communities, at a regional scale the conurbation space between cities is also reclaimed by different actors and agencies. Recognised as less regulated spaces, conurbations are used for community projects that improve the social and environmental resilience of large regional systems (Yong et al. 2010, Živanović-Miljković et al. 2012). The factors that explain this capacity of some spaces to absorb different functions are multiple, although there is a certain consensus that multifunctionality can flourish in those less regulated spaces where institutional constraints are somehow absent, away, or are flexible enough to allow alternative temporary uses or 'particular forms of urban practice' (McFarlane 2012: 89).

It is known that interstitial spaces improve the resilience of cities and reinforce their urban condition. If we assume that urban resilience relates to the capacity of an urban system to absorb different types of turbulence, retain substantial functions and structure, and recover its lost functional capacities while undergoing change (Wardekker et al. 2020), the porosity defined by the system of interstitial spaces plays a critical role in defining climate-responsive cities that ensure urban sustainability (Figure 2). 
The built-up city

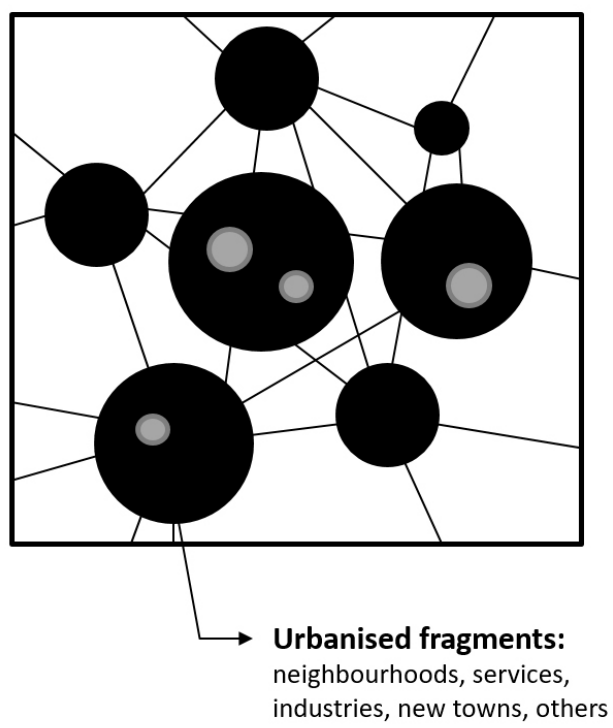

The interstitial spaces

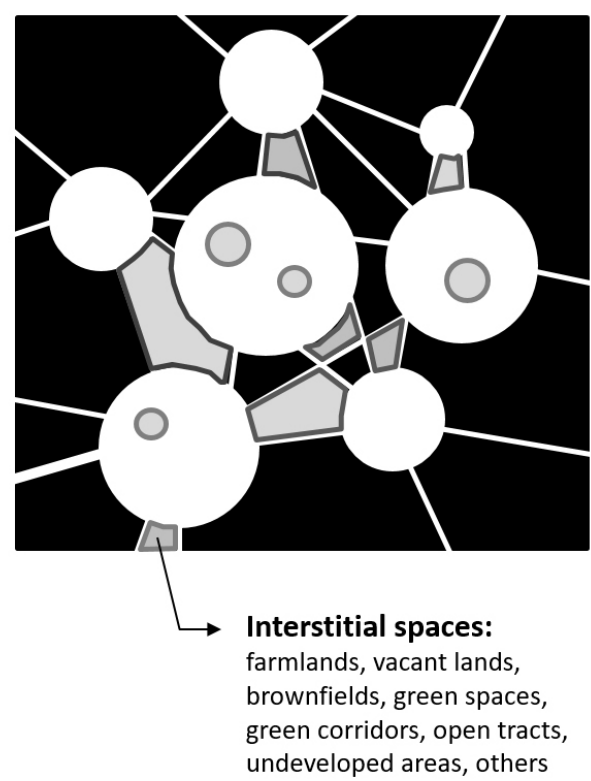

Figure 2. The built-up city and the interstitial geography (author's diagram).

\section{Methodology}

\section{Choosing Santiago de Chile's interstitial spaces}

The analysis presented in this paper is illustrated through the case of the capital city of Chile-Santiago - specifically focusing on its south metropolitan expansion as it appears to be the most important axis of sprawling suburbanisation (Borsdorf et al. 2007). The city is used as a basis for abstraction and generalisation, though the role of interstitial spaces in creating climate-responsive cities has salience to the vast majority of urban areas. Santiago de Chile provides a good example of the significance of interstitial spaces in a context of urban sprawl, specifically as it illustrates common patterns of urban development observed in most Latin American cities (Coq-Huelva \& Asián-Chaves 2019). As a metropolitan area, Santiago is composed of 36 independent communes and has a total population of 7,112,808 inhabitants. As such, it represents 40.5 per cent of the country's population (INE 2017) confirming a high national demographic concentration. Santiago's urban development is characterised by a sprawling pattern of urban growth (Silva \& Vergara 2021) mainly defined by transport corridors (Flores et al. 2017), peripheral concentration of social housing developments (Coq-Huelva and Asián-Chaves 2019), high rates of land fragmentation (Inostroza et al. 2013), the presence of active farming areas (Silva 2020), 
unregulated urbanisation beyond the urban limit (Flores et al. 2017), inequal distribution of green and open space (Banzhaf et al. 2013), and high-rates of sociospatial segregation (Cox \& Hurtubia 2020). The city reflects planning rationales adjusted to facilitate urban growth supported by privatisation of land and infrastructure (Zegras 2003), and centralisation of social housing supply (Heinrichs and Nuissl 2015). Taken from the southern sprawling space of Santiago - that shows a significant number of interstitial spaces - a few interstices are used to illustrate their environmental values, relationality, and the scale at which they are manifested, and how they qualify Santiago's suburban landscape as a potentially climate-responsive context. The three types of interstices selected for analysis are: a) The 'Huertos Obreros y Familiares de la Pintana' [Worker and Familiar Orchards of La Paintana commune] (a cluster of small-scale agricultural plots; this case is also collated with the nearby farming land of La Platina and Campus Antumapu), b) the extraction mining site of La Florida/Puente Alto, and c) southern metropolitan conurbation space (Figure 3).

The selected interstices describe the previously discussed key attributes of environmentally flexible spaces (environmental capacity, spatial variety, and multifunctionality) that allow adaptation capacities and mitigation strategies against climate change and natural disasters, and improvements in social and environmental resilience. Aside from the conurbation space - where a lineal axis of about $35 \mathrm{~km}$ is

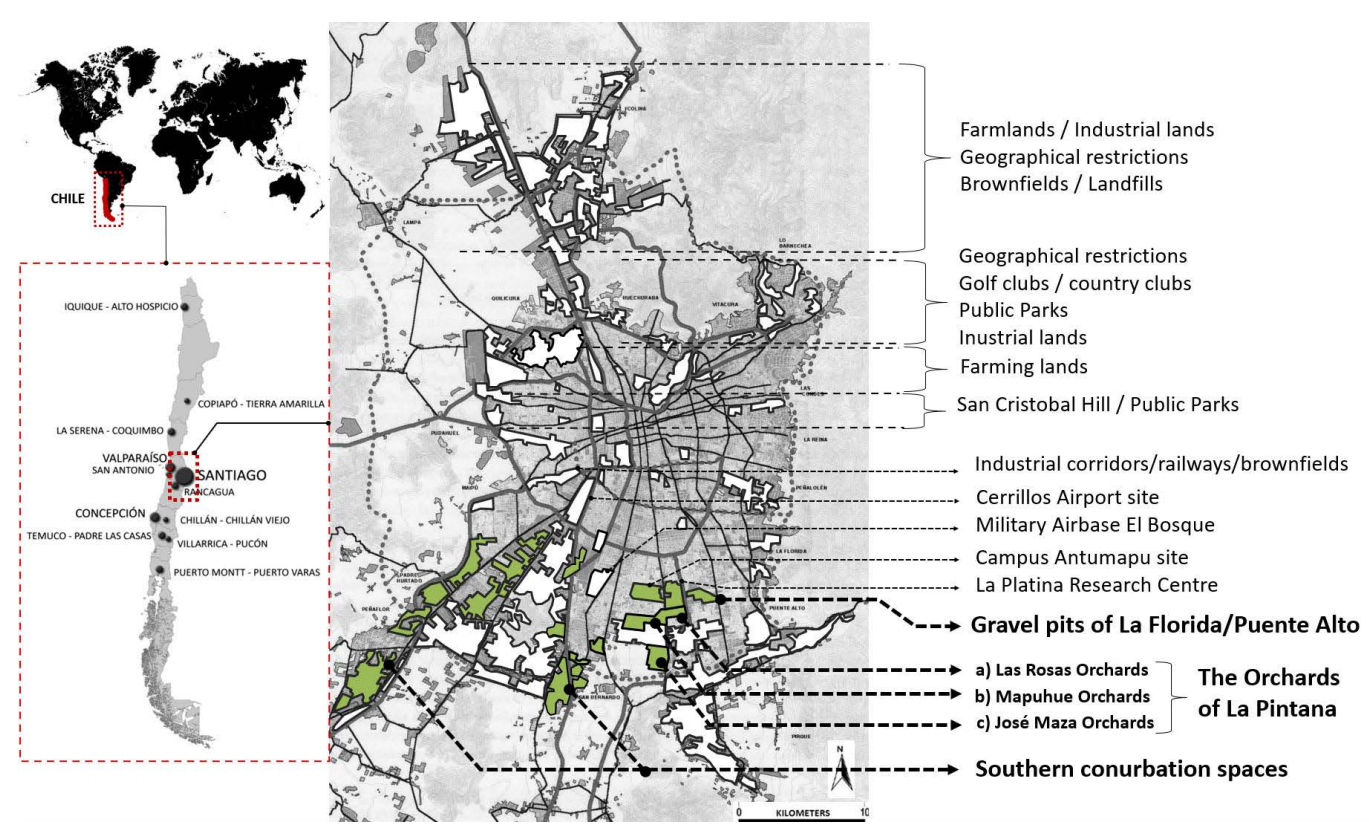

Figure 3. Map of Santiago, its interstitial spaces, and the selected interstices for analysis (author's map). 
taken - the orchards of La Pintana and the extraction (mining) site of La Florida/ Puente Alto are about 300 hectares each, representing an attractive size for new urbanisation. These areas are identified by various actors as 'strategic' in light of their location, land capacity, and connectivity, and appear as contested spaces as various public-private agencies operate upon their land management and possible future destinations.

\section{Research design and methods}

The findings presented in this paper are the outcomes of case-study researchconducted between 2016 and 2021 — based on a mixed methodology that articulated qualitative and quantitative data (Tashakkori \& Creswell 2007). Considering the varied spectrum of interstitial spaces, the research adopted a 'multiple case-study approach' (Burawoy 1991, Flyvbjerg 2006) to encompass a representative range of cases and generalise conclusions. The methods included mapping Santiago's urban development and interstitial spaces to analyse its morphological, spatial, and environmental characteristics.

Document review was used to examine policy conflicts and the views of planning authorities on Santiago's urban development and interstitial spaces. This allowed an examination of how urban policies influence the proliferation of interstitial spaces in Santiago. The policy review was based on Bowen's approach (2009) in which documents are politically mediated 'social facts' that provide findings, policy priorities, and interpretations on Santiago's urban development, projects, plans, and synthetised data. The analytical procedure considered thematic analysis (Kiger \& Varpio 2020) to organise and codify data and policy narratives into three categories that describe the environmental nature of interstitial spaces: a) the policy and environmental values of interstices, b) the spatial attributes of interstices, and c) the functions (and formal/ informal land uses) of interstices. This information was collated with statistics on demography (INE 2017), land and housing market fluctuations, regional economic development, environmental policies, and findings from secondary research on Santiago's environmental sustainability (Evans \& Lewis 2018). Selected quotations were also taken and organised into major themes, categories, and case examples specifically through content analysis (Gavin 2008). Consulted reports included The National Policy of Urban Development (MINVU 2014a), various statistical reports from the Institute of National Statistics (INE), the Metropolitan Development Plan of Santiago (PRMS100; MINVU 2014b) and various local development plans, communal master plans, urban design proposals, reports from the Ministries of Public Works, Environment, Agriculture, and Housing and Urban Development (MINVU) inter alia. 
The data found in policy reports were also collated with primary data gathered from fifty-six semi-structured interviews (Galletta 2013, Stender 2017) that included a range of interviewees selected for their first-hand knowledge of Santiago's urban development and the environmental attributes of its interstitial spaces. The interviewees included high-level planning authorities, policymakers (metropolitan/municipal), politicians (deputies, senators), urban designers, developers, local residents, agricultural scientists, and members of social and environmental organisations and NGOs. The datasets of semi-structured interviews generated during and/or analysed during the current study are not publicly available due to restrictions imposed by the ethical assessment of the research (Ethic Application ID: 5588/001 2014, UCL) that required interviews to be anonymised so that the respondents could be frank, without fear of professional repercussions. Questionnaires inquired into three specific subjects related to Santiago's urban development and interstitial spaces: a) Santiago's pattern of urban sprawl, b) Santiago's interstitial spaces, and c) the politics and implications of interstices on Santiago's urban development. Statistical data on Santiago de Chile, Chilean population, housing stock and others from institutional sources are publicly available through the links indicated in the reference list of this paper.

All the information was corroborated and complemented through site visits where direct observations were undertaken to evaluate the urban quality, physical infrastructure, accessibility, spatial boundaries, land uses, (in)formal occupations, quality of surroundings, relationality, and environmental characteristics of selected interstices. Since secondary research on these sites is limited, site visits were necessary to obtain a comprehensive understanding of existing environmental conditions. The visits were based on Rayback's approach, who indicates that observations, visual records, and measurements make it possible to address more than one site to compare and contrast, establish commonalities and differences, and test whether or not a site finally meets the study goals (Rayback 2016).

\section{The interstitial spaces of Santiago's urban sprawl}

Santiago's urban sprawl describes a wide spectrum of interstitial spaces recognised as diverse in terms of morphology, size, location, and environmental properties. The types of interstitial space found in Santiago include agricultural and industrial land, brownfield, landfill, public spaces, geographical restrictions, conurbation zones, former airports, military facilities, small-scale farming areas, research centres, infrastructural spaces, and buffers of security inter alia. Some of them are currently well located near transport, energy supply, services, and populated surroundings that make them attractive for both public and private investments. As such, they are perceived by 
different agencies and social-based organisations as an opportunity to change suburban inertia mainly driven by the social housing agenda. The diversity of Santiago's interstices also relates to their origins and multilevel modes of governance, as some interstices are outcomes of land privatisation, financial speculation, geographical and physical constraints for urbanisation, planning restrictions, and disparities between landowners and public agencies regarding their future destinations (Silva 2019). Given that some interstitial spaces describe agricultural land-uses, for instance, they are managed by the Ministry of Agriculture although immersed within the suburban fabric they are also part of the plans of the Ministry of Housing and Urbanisation (MINVU).

In Chile, aggressive policies of land privatisation over the past forty years have increased land subdivision, thus resulting in the creation of clusters of small properties that affect large-scale interventions (Santiago et al. 2016). In this scenario, some landowners agree to develop their land while others do not. This ends up creating clusters of built-up areas mingled with interstices. Conurbation zones are also examples of large areas driven by transport infrastructure and de facto developments that define a pseudo-urbanised landscape where different uses are interspersed with undeveloped land. As mentioned, gaps in governance also determine the emergence of interstitial spaces. These are the cases of shared boundaries between different municipalities in which local authorities tend to leave them without services, houses, or any kind of infrastructure. Local mayors place their interventions in central areas to serve their own taxpayers and voters, thus ensuring that local residents perceive the benefits of their political leadership (Silva 2019). Regulatory constraints also define 'restriction zones' as areas where urbanisation is prohibited. This is the case with ecological reserves or protected historical sites. Other factors that encourage private landowners to keep their land undeveloped over time include land banking and land speculation (López-Morales 2011).

As proposed in this paper, the environmental approach to studying the interstices is structured by the environmental values of interstices, their spatial attributes, and their flexibility to adopt different functions at regional levels. In the case of Santiago, this approach will be examined through the cases of farming land, the extraction mining site, and the conurbation space.

\section{Santiago's suburban rurality: the orchards, La Platina, and Campus Antumapu}

For scholars and consultants on environmental sustainability, the southern interstitial spaces of Santiago appear to be 'healthy spaces'. As such, they contribute to the ratio of open space that diminishes the impacts of urban pollution. In this category, suburban farming plots have a key role in providing green space, clean air, quiet 
environments, and workplaces for local communities. These types of rural interstices are mainly located at La Pintana commune - recognised as the commune with the most fertile land in the whole metropolitan region (ODEPA 2012, SINIA 2012). These interstices are used for agricultural production, but nevertheless experience tension from planning demands linked to housing shortages. These are the cases of La Platina site (Ministry of Agriculture), Campus Antumapu (Universidad de Chile), the Tocornal and Concha y Toro vineyards, and the 'Huertos Obreros y Familiares', all recognised as 'foodscapes' by NGOs, the Food and Agriculture Organization, and social organisations. Considering their current location within the urban hinterland, these interstices have become seminal expressions of 'urban agriculture' and natural heritage related to historical practices in agriculture and social housing (Roubelat \& Armijo 2012).

The most prominent example is the above-mentioned 'Huertos Obreros y Familiares' - a cluster of half-hectare orchards created in the 1940s and named Las Rosas, Mapuhue, and José Maza. The orchards have become a self-contained environment where families cultivate food to ensure their own subsistence and to distribute to the metropolitan region. These interstices define a category of suburban rurality wherein urban and rural identities coexist (Catalán et al. 2013). Despite development pressures, the land is protected by Law 6.815 — enacted in 1941 (known as 'José Maza Law') - which has ensured its preservation over the years as it does not allow land subdivision. The orchards have been historically managed by the original families and their descendants, and after years of cultivation they have been recognised internationally for the provision of organic, healthy, and seasonal food (Figure 4). They help to reduce the temperature of the whole metropolitan region through evapotranspiration, showing a difference in temperature of $4^{\circ} \mathrm{C}$ in comparison to neighbouring communes. The orchards also ensure natural irrigation by surface water, avoiding flooding, which makes the commune comparatively more resilient (interview with the Director of Environmental Operations. Municipality of La Pintana, June 2014). This is a recognised trait in a city like Santiago where the loss of green spaces implies a significant loss of infiltration, cooling, and retention capacities that leads to greater hazard exposure (Krellenberg et al. 2013).

Several studies have confirmed the importance of the orchards, considering the scarcity of green spaces in Santiago and the unbalanced distribution of green infrastructure among suburban municipalities (Escobar 2006). For planners and developers alike, this disparity must be combatted through their preservation as they help in decreasing environmental injustices. For scholars, policymakers, and social organisations these interstitial spaces can be part of a wider interconnected system of public venues that integrate the spectrum of derelict and undeveloped land with the city. 


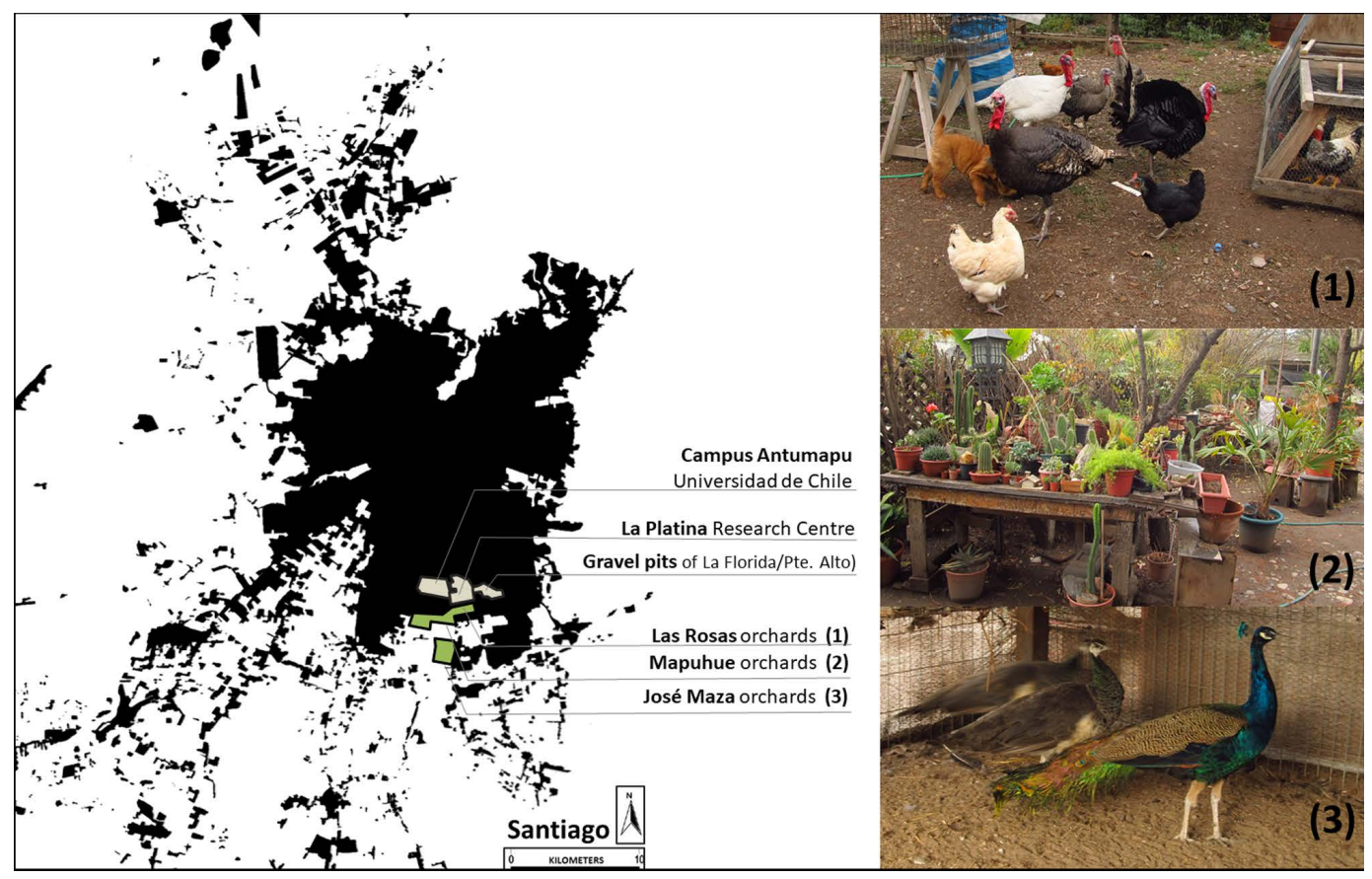

Figure 4. Location of the agricultural sites of Campus Antumapu, La Platina, and the 'Huertos Obreros y Familiares' of La Pintana [Workers and Familial Orchards] (author's map and photos, 2020).

The orchards of La Pintana as interstitial spaces within southern Santiago have an enormous environmental and educational impact, which can be amplified if connected to other places and the surrounding neighbourhoods. You can take the kids there to see the spiders, animals and birds, or simply to enjoy the wild nature or reinforce their social relationships. Unfortunately, internal rural spaces (as almost everything) are seen as 'commodities' and when they are not productive, they become urbanised. So, their intangible values are not included in the economic equation although they must (interview with Professional Advisor, National SEREMI of Agriculture 2010-14, May 2014).

This integration implies 'a modernisation of the Chilean planning system to include the intangible and hedonic value of interstices, and appeal [against] the capitalist agenda that is known to commodify the land. This would affect the taxation system by including criteria of environmental and socio-cultural benefits' (interview with the Director of Urban Project Ciudad Parque Bicentenario, MINVU, May 2014). It is argued that the orchards can be connected to several local hills, valleys, and even cliffs. This, in turn, adds spatial complexity to the city by incorporating further functions related to leisure, education, sport, and appreciation of nature. 
These interstitial spaces provide natural soil that should be maintained, even when they are not agriculturally productive. The unique experience of seeing the trees is a value in itself. There is a difference between 'value' and 'price', and natural spaces such the orchards of La Pintana matter because of their 'values'. These spaces also have a history to be preserved that could be part of the heritage for future generations (interview with the President of the Water Community Villa Las Rosas, La Pintana, June 2014).

For residents, these interstitial spaces can host activities such as camping, swimming, different types of sports, and city farms, typically found 'outside' the city. These functions can improve social acceptance of Santiago's sprawling context and, thus, its social resilience. 'Suburban families that cannot afford to activities outside the city could use these interstices as alternatives for leisure and recreation' (interview with Professional Advisor, the National Service of Environmental Evaluation. Ministry of Environment 2014). The cases of La Platina and Campus Antumapu-also at La Pintana commune - describe a strong 'provincial atmosphere'; these are landscapes where it is possible to see the Andes Mountains, the trees, the sun, and the skyline of the city (Figure 5). Local residents perceive these places as natural references for how seasons change during the year; a privilege for low-income families that are unable to go outside the city to enjoy nature:

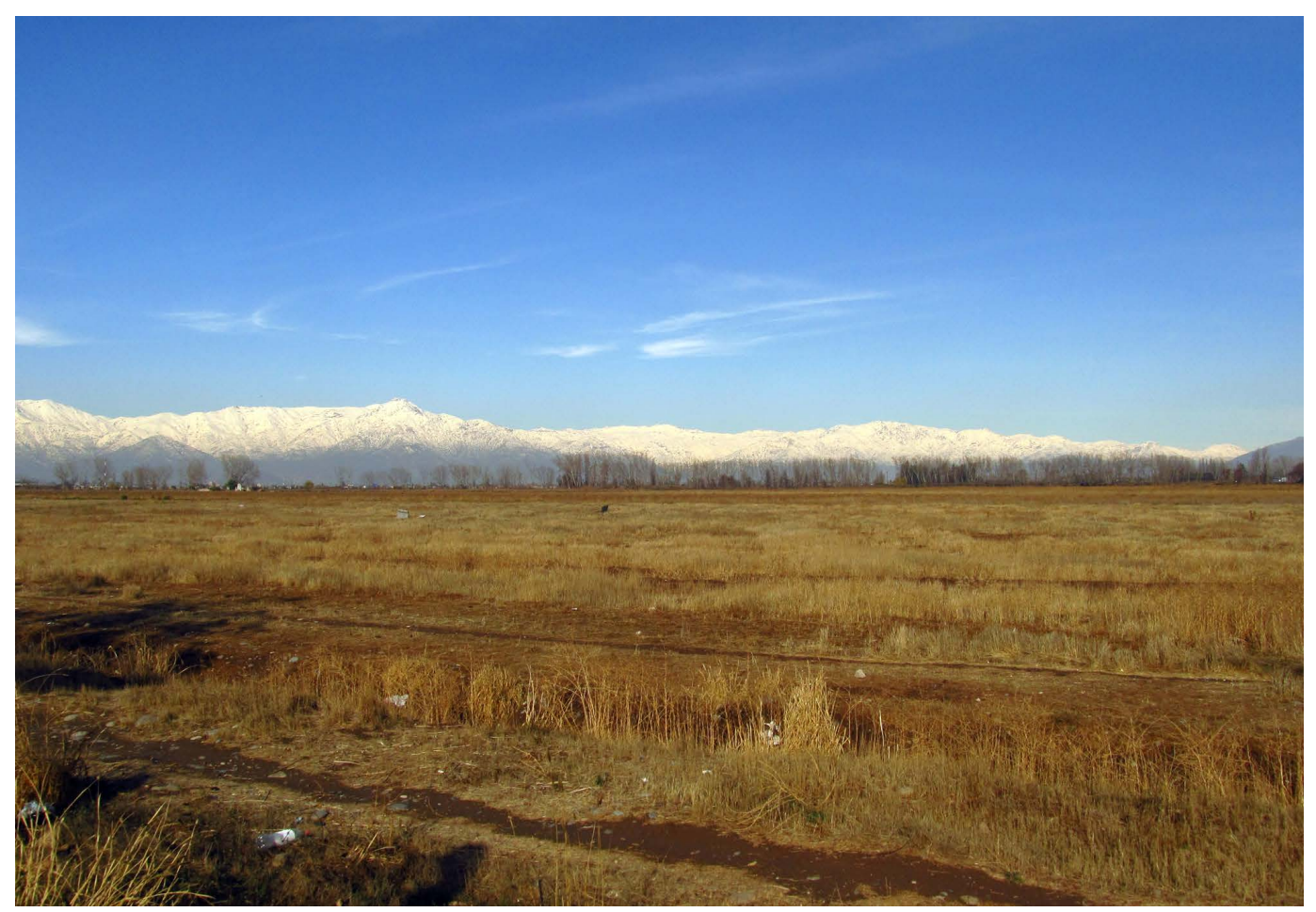

Figure 5. La Platina site, La Pintana commune (author's photo. May 2016). 
La Platina is a piece of countryside within the fully urbanised area ... good to have a diverse landscape in which open spaces offer beautiful views; a break in our homogeneous routines. This space [La Platina] can be a park, which is not only a public space for the area but also for Santiago. These areas should remain open as we have a lack of green space and our homes are quite small. In my case, for instance, I used my small private yard to build a roof for the car! That was the end of my own little open space ... and is the same for everyone here. So, these interstitial spaces are the best chance to supply green space for everyone. This really makes us stronger as community to overcome economic and social difficulties (interview with resident of Villa Ambrosio III, La Pintana commune. June 2014).

These spaces also add value to surroundings and influence decision-making when choosing a place to live. These values relate to the presence of nature and how it provides specific features and identity to the area. They are also perceived as safer in a country that is vulnerable to flooding and other natural disasters, and where the agenda of risk management has become a national priority:

When we arrived here [ten years ago] this place [La Platina] was fenced. So, we received the house from the government with a beautiful landscape in front of us ... a place covered by plants, vegetables and flowers. Actually, the most amazing views were those of the marigolds that made the landscape so beautiful. These places make our neighbourhood more beautiful. It was one of the reasons why we agreed to come here. It is a huge place in which you can find the openness ... and that's why our neighbourhood is never flooded. This is also a place we use to escape when there is a shake [earthquake]. We just run into the site and we are all safe! (interview with resident of Villa San Gabriel, La Pintana commune, June 2014).

\section{Santiago's three-dimensional landscapes: the extraction (mining) pits of La Florida}

The presence of industrial land in southern Santiago defines a category of interstitiality that contrasts with the homogeneous (plain) suburban landscape of social housing developments. In particular, a series of interconnected gravel pits located in the boundary between the communes of La Florida and Puente Alto cover an area of about 300 hectares. The pits have been used to extract raw material during the last fifty years. Due to the continuous excavations, the resulting landscape is an uneven geography of interconnected 'holes' of different lengths, widths, and depths. The stones, gravel, rubble, etc also contribute to define a landscape that clearly contrasts with the housing developments that surround the pits. Somehow, these pits have become the backyard of many houses located just in the border. These homes have gained privileged views over the system of interconnected gravel pits although reported accidents relate to the lack of fences, electric light in the night, security, and anti-social behaviour (interview with the Director of Urban Planning, La Florida commune, June 2014) (Figure 6). 


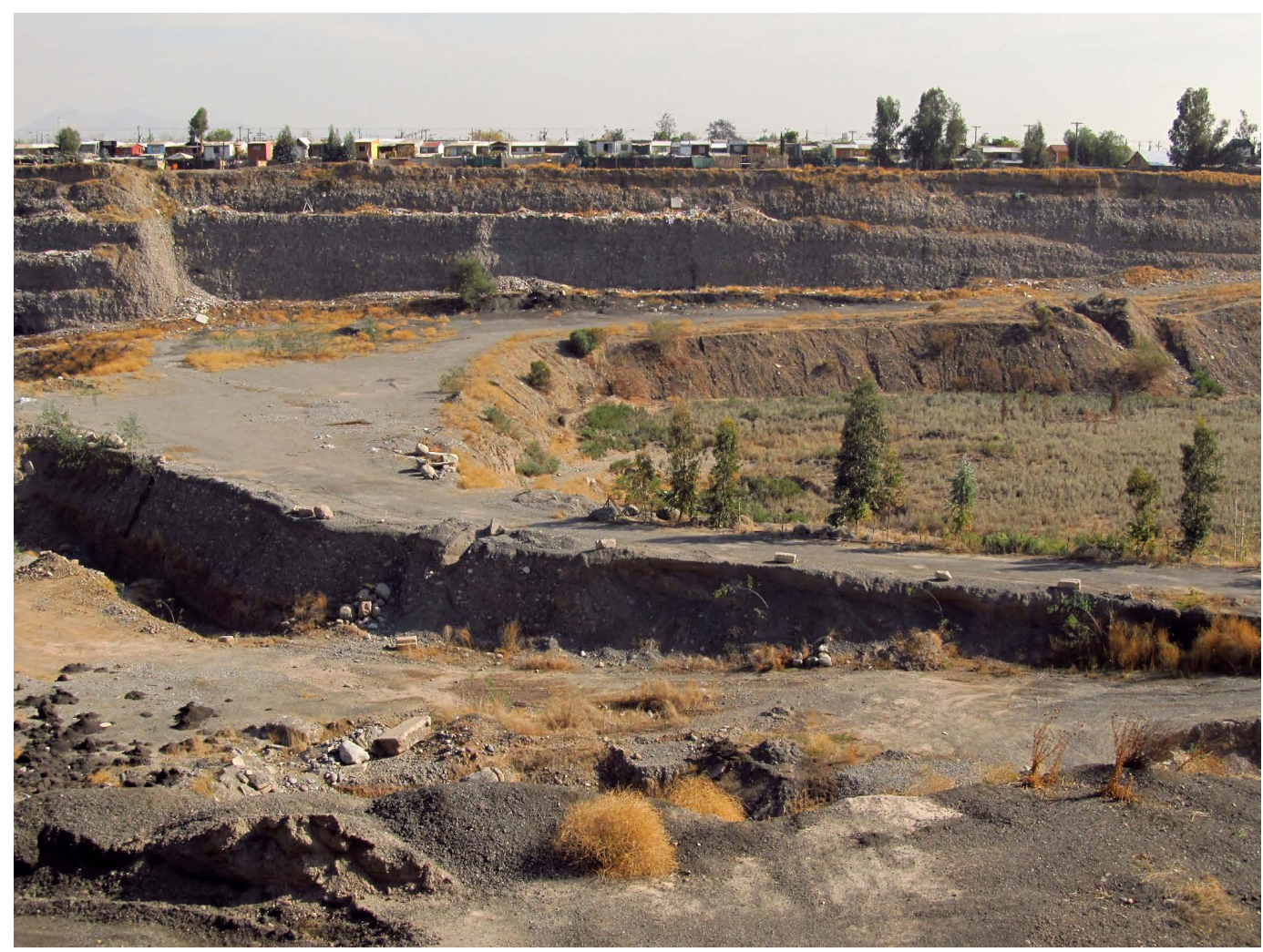

Figure 6. The interconnected extraction sites at the boundary of La Florida and Puente Alto (author's photo. May 2016).

The pits are a cluster of private properties in the hands of different owners-with restricted public access - and in which extraction of raw material is combined with industrial storage of rubble. The industrial activities interfere in the lives of local residents who complain about air pollution, noise, and lack of safety given that the site does not have proper fences against the deep excavations. Although extraction has dwindled to a now negligible activity alongside some very minor construction-related activities, the area remains classed as 'industrial' but is effectively an interstitial space. As decaying or blighted spaces, the pits are nevertheless 'pending'; framed by variable timelines over which they may become developed at some point. Additionally, this space suggests unprecedented coordination at multiple levels resulting from its location in a boundary area.

Aside from its morphological attributes, the pits are also recognised as large and efficient bowls of collection of local and metropolitan stormwater. At municipal levels, it has been calculated that a substantial fraction of superficial water ends up in the pits. This situation triggers differing ideas regarding future reconversion: while 
some central and local authorities advocate filling in the pits to relocate more social housing developments, others see the pits as a future metropolitan park that can both absorb stormwater and provide communal green space (interview with the Chair of Urban Planning of the Municipality of La Florida, May 2014). Studies conducted by the MINVU in 2001 defined the area as suitable to be connected with other neighbouring interstices - La Platina and Campus Antumapu - and proposed a metropolitan park with a total intercommunal space of around 794 hectares. As such, the park would benefit about 1,100,000 inhabitants (Figure 7). Environmental assessments indicated that the provision of green spaces would serve as an efficient receptor of superficial flooding that would improve the metropolitan resilience:

It was determined that the area should be intended to create a large ecological recreational centre ... a mega-park, a park of the southern zone. This would also balance the lack of green space and would provide drainage for large flooding in winter. It is known that in the south we have in average less than $9 \mathrm{~m}^{2}$ of green space per person-far below what is indicated by the $\mathrm{WHO}$ - but after doing these studies we realised that the whole environmental performance of the area can be improved, including flooding adaptation. We concur with central authorities in also having here the metropolitan zoo-so, we applied to host it at La Platina (interview with the Director of Urban Planning of the Municipality of La Platina, May 2014).

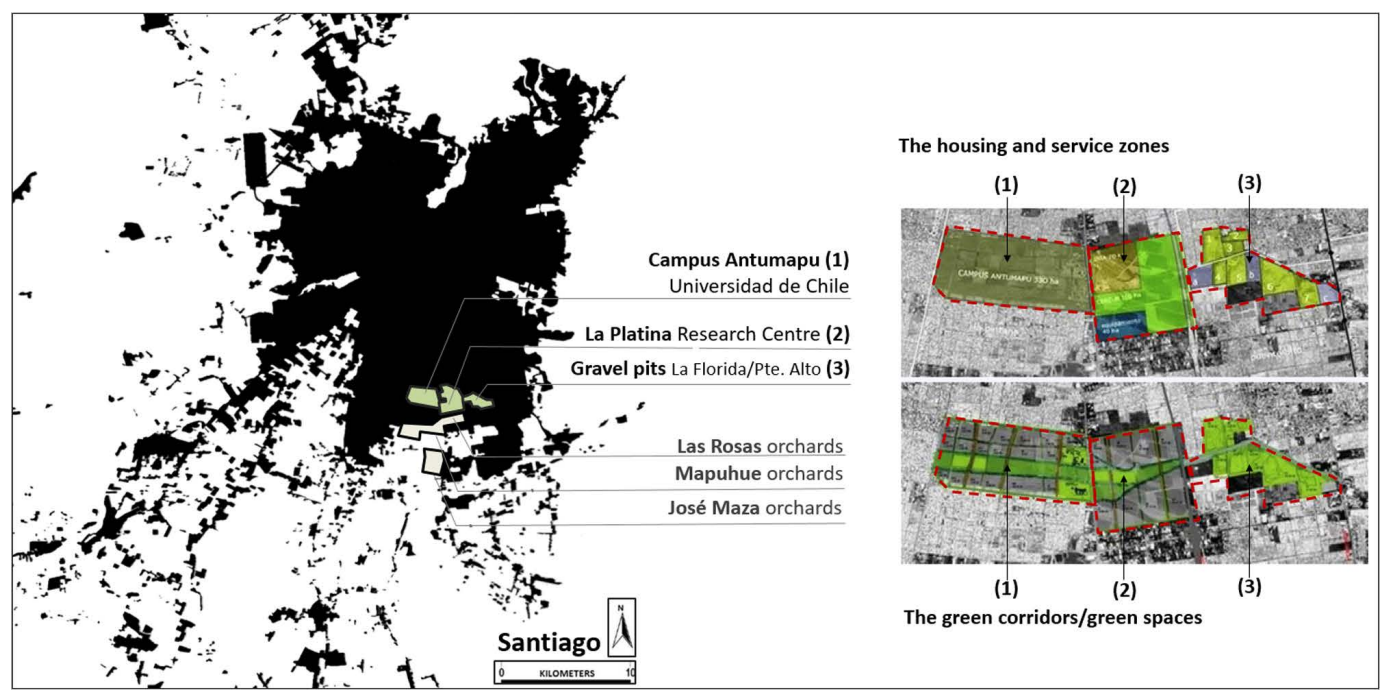

Figure 7. Master plan of the 'Parque Sur' project connecting the sites of Campus Antumapu, La Platina, and the extractions sites of La Florida/Puente Alto (author's map, based on EMB Construccion Magazine, 2016). 
La Platina would also witness better housing projects, and the Antumapu site would remain as a large-scale green area. According to local authorities, the transformation of these interstices into a large interconnected park would define a symbiotic relationship with the communal rural functions:

This commune is in a very good position to address these challenges and contribute to the maintenance of the metropolitan zoo and the park. Why? Because 50 per cent of our commune is rural, and we are able to produce food for the animals and provide maintenance. This is a unique condition as we have the rural plots and the urban farmers [huerteros]. With our know-how and technicians there is no doubt that we would be more socially and environmentally sustainable (interview with the Director of Environmental Management of the Municipality of La Pintana, June 2014).

\section{The multifunctional regional interstices: the southern conurbations}

The southern conurbations of Santiago define another category of interstitiality that illustrates different relationalities, morphologies, and resilience capacities. Despite appearing as open spaces, they are formed by different sub-interstices and built-up areas with different functions. Santiago's southern conurbations are a complex mix of unregulated and regulated land that define an ambiguous landscape in which housing projects, farming areas, and infrastructure coexist.

Owing to the infrastructure and lack of constraints on rural land, the resulting in-between spaces become accessible to new developments that diminish the environmental capacity to manage superficial flooding in these zones. This has been noticed by private owners of industries and housing developments, although they do not see themselves as contributors to this environmental deterioration (interview with the Chair of Urban Planning of the Municipality of San Bernardo, May 2014). Cases in points include the conurbations between Maipú and Padre Hurtado-structured by the 'Autopista del Sol' [The Sun Motorway] and 'Camino a Melipilla' [Melipilla Road] - as well as the conurbation between southern Santiago and San Bernardo structured by the 'Autopista Central' [Central Motorway] (Figure 8).

The first conurbation between Maipu and Padre Hurtado is primarily explained by the growth experienced by the commune of Maipú - that along with Puente Alto-has concentrated 70 per cent of the increase in population after 1978. These were the two most populated communes in Chile between 1982 and 2002 (Tokman 2006). Empirical studies show a clear concentration of social housing units in these communes between 1979 and 2002 (Hidalgo 2007, Tapia 2011) — with an increase in communal land prices (Brain \& Sabatini 2006) - that derived into the inclusion of these communes in the last modification of the Metropolitan Regulator Plan of Santiago (PRMS100; MINVU 2014b). In 1994, the urbanised area of Maipú reached 


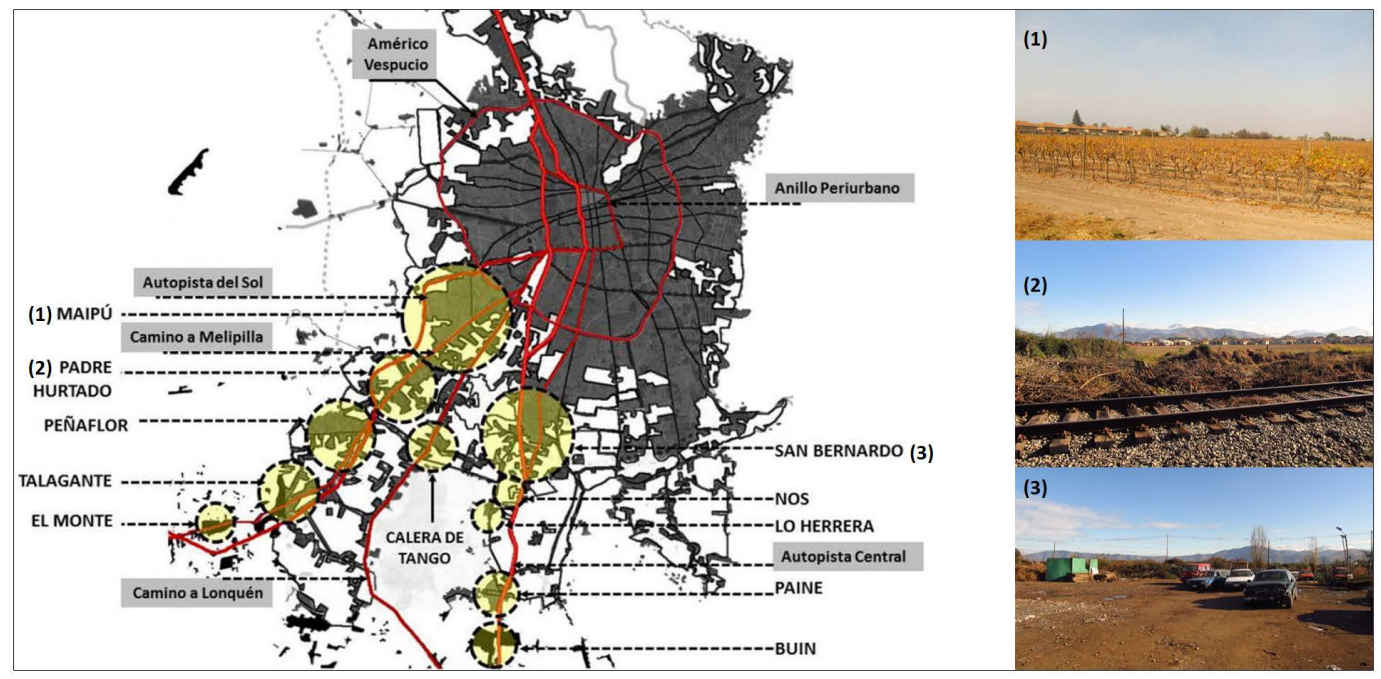

Figure 8. Santiago's southern conurbations and the common sub-interstices of Maipu, Padre Hurtado and San Bernardo (author's map and photos, 2020).

the boundary of the neighbouring commune of Padre Hurtado, which was also included in PRMS100. By diminishing the hectares of rural land, this rapid growth has confirmed sprawling growth with strong connection to environmental hazards for Santiago de Chile (Krellenberg et al. 2013). However, one of the most recognised characteristics of Maipú and its conurbation space is its adaptation to these drastic changes, their increasing multifunctionality, and general improvement in urban quality. Here, farming areas, infrastructure, upper-class residential developments, low-income neighbourhoods, industrial facilities, open spaces, educational and commercial services, research centres, historical heritage, green infrastructure, sporting clubs, small villages, etc, shape 'a collage' of elements that speak about flexible planning restrictions, the supremacy of land tenure, and transport corridors as main determinants of the overall morphology.

The second conurbation space is derived from the expansion of the neighbouring southern commune of San Bernardo. The commune is also included within PRMS100 - a modification that increased the communal land from 5,400 hectares to almost 9,000 hectares (more than a 70 per cent) —aimed at absorbing around 64 per cent of residential growth (Boccardo 2011). San Bernardo had to change its urban limits to include more housing developments, green spaces, connectivity, and the reconversion of industrial land. The commune is considered a 'sub-centre' of Santiago: an area with high levels of functional self-sufficiency (PLADECO 2011). The plan includes a small rural village called 'Lo Herrera' - a distance of $15 \mathrm{~km}$ from San Bernardo's city centre - and other in-between rural plots for future growth. Some of 
these land are labelled 'special uses', and others are security buffers, underused infrastructure, military installations, and sports facilities. Some geographical handicaps - such as the Cerro Chena and a large gravel pit - appear as geographical restrictions; others as abandoned spaces that 'can be part of the environmental assets of the commune if properly included in metropolitan plans' (interview with the Chair of Urban Planning of the Municipality of San Bernardo, May 2014). The commune is recognised as one that is experiencing the most radical changes in its rural identity, mainly marked by the extensive location of social housing developments (J.M.E. Vidal 2020).

As seen through the case of Santiago and the selected interstices, the analysis of interstitial spaces can be addressed with regard to its environmental potential, spatial attributes, and multifunctional capacities at regional levels. The case of Santiago de Chile sheds light on the role of interstitial spaces in contributing to the social and environmental resilience of cities, and their spatial and functional adaptation. The theoretical approach and the case of Santiago also provide a more comprehensive understanding of the nature of interstices as spaces that are not only 'green'. In that sense, the research contributes to amplifying the spectrum of land that can be considered part of the environmental assets of cities, usually addressed by closely related literature on green infrastructure, natural capital, environmental services, and urban sustainability. The studies of interstices can involve a more interdisciplinary approach to also complement the literature on suburbanisation, urban sprawl, and urban governance for the improvement of community resilience and the preservation of multiple environmental assets. In the case of the orchards, for instance, bottom-up initiatives counteract hegemonic modernisations driven by the massive production of social housing, market-driven infilling policies, and the use of vacant land for regional transport infrastructure. In the case of the mining site of La Florida/Puente Alto, the uneven geography resulting from the extractive activities provides a spatial and environmental variety with enormous potential to absorb functional and environmental changes at local and metropolitan levels. If integrated into planning, it can inspire innovative design solutions to absorb extreme rainfall while providing a large-scale public space. However, this case unveils the inertia of planning aimed at undertaking urbanisation on level ground and thus promoting re-filling rather than adapting policies to accept its interstitial condition. Finally, the conurbations pose major environmental and governance challenges considering their piecemeal consolidation as hybrid spaces composed of urban and environmental assets. Their multifaceted nature in terms of infrastructure suggests further reflections around their autonomy as distinctive geographies of regional significance. Here, multifunctionality, environmental hybridisation, and specific forms of rural-urban practices are natural features that dispute the notions of suburbanisation and rurality. Contrary to what the interstices 
suggest, however, the political impulses to 'fill the gaps' reflect a long-standing will of modernist-inspired nations - driven by the values of a neoliberal agenda - that codifies the interstices as wasted land rather than environmental assets that must be preserved (Phelps 2015). Indeed, the intense concentration of social housing developments and the implementation of regional motorways in the south axis of Santiago may account for the scale of the subsequent dysfunctionalities of suburban sprawl; all contradictions in the accumulation process now have to be addressed by further rounds of state interventions - such as the new version of the NPUD/2014 (MINVU 2014a) - which interstitial spaces are not part of.

The approach proposed in this paper-structured by the environmental potentials of interstices, their spatial attributes, and their multifunctional capacities to absorb changes and mitigation strategies - has salience to the vast majority of cities characterised by processes of land fragmentation and urban sprawl. The findings presented here can also serve as a reference for an analysis of cities where the spectrum of interstices varies in quantity and type. In that sense, other cities can contribute to bulk up the repertoire of interstitial spaces along with their varied environmental implications and the politics associated with the type of resilient suburbia that they suggest.

\section{Conclusions}

Although less recognised in the planning literature, the interstitial spaces that are produced alongside the urbanisation process are substantial components of the sprawling geography of city-regions. Ranging from liminal spaces between buildings up to the regional space between cities, interstitial spaces describe different levels of relationality that connect or separate surroundings. As part of their nature, the system of interstitial spaces is far from being static, empty, or inert. Instead, interstitial spaces present a range of attributes that can be analysed through their environmental potentials, spatial attributes, and flexibility to absorb different functions and changes. The interstices increase the porosity of cities and qualify the built environment through their spatial values as in-between land. On this basis, it is argued that interstitial spaces can play a key role in the resilience and adaptation capacities of cities, and improve their condition as climate-responsive environments against the impacts of climate change and natural disasters. Assuming the environmental potential of interstitial spaces, they can also help in combatting the unsuitable character of sprawling growth and consolidate processes of land fragmentation as source of interstitiality.

As demonstrated through the case of Santiago de Chile, the interstices configure a diverse spectrum of land with differing relationalities and environmental services. They suggest new categories of public land with the potential to activate suburban 
areas, attract wildlife, accumulate rainwater, facilitate risk management during natural disasters, improve the adaptation capacity of local communities, and improve the overall urban resilience. As demonstrated by the case of the orchards and other farming spaces, farming interstices suggest alternative conceptions of rurality, green infrastructure, multifunctionality, natural and cultural heritage, and social resilience. The extraction sites of La Florida, demonstrate the spatial versatility of the interstices as 'ever-changing geographies' that can accommodate new environmental functions and absorb drastic changes triggered by accelerated processes of suburbanisation. The conurbation space of Santiago represents an opportunity to articulate multifunctional land uses beyond binary urban-rural oppositions. Beyond the case of Santiago de Chile, it has been clarified that interstitial spaces define a spatial system in its own right that can be better equipped to absorb environmental shocks while securing urban functionality. This raises further questions around the planning and design challenges associated with the interstitial spaces, and the political meanings associated with the creation of sustainable urban environments through the production of interstices as another mode of the production of the space.

\section{Acknowledgements}

The author thanks the reviewers for their observations, and the interviewees for their valuable insights and the information provided on Santiago's urban development. This work was supported by the National Commission of Science and Technology of Chile (CONICYT), Grant 72110038; the School of Natural and Built Environment (SNBE), Queen's University Belfast (QUB), Grant D8202PAC.

\section{References}

Anuar, M.I.N.M. \& Ahmad, R. (2018), 'Exploring the Urban Interstitial Spaces and its Potential Usage at DUKE Highway', Asian Journal of Quality of Life, 3(13): 48-59. https://doi.org/10.21834/ajqol.v3i13.161

Arboleda, M. (2016), 'In the Nature of the Non-city: Expanded Infrastructural Networks and the Political Ecology of Planetary Urbanisation', Antipode, 48(2): 233-51. https://doi.org/10.1111/anti.12175

Arboleda, M. (2020), Planetary Mine. Territories of Extraction Under Late Capitalism (New York, Verso).

Banzhaf, E., Reyes-Paecke, S., Müller, A. \& Kindler, A. (2013), 'Do Demographic and Land-use Changes Contrast Urban and Suburban Dynamics? A Sophisticated Reflection on Santiago de Chile', Habitat International, 39: 179-91. https://doi.org/10.1016/j.habitatint.2012.11.005

Batty, M. (2016), 'Empty Buildings, Shrinking Cities and Ghost Towns', Environment and Planning B: Urban Analytics and City Science, 43: 3-6. https://doi.org/10.1177/0265813515619858 
Bertino, G., Fischer, T., Puhr, G., Langergraber, G. \& Österreicher, D. (2019), 'Framework Conditions and Strategies for Pop-up Environments in Urban Planning', Sustainability, 11(24), 1-30. https://doi.org/10.3390/su11247204

Boccardo, D. (2011), 'Tensions of a Triple Urban Vocation: San Bernardo Bernardo and its Absorption Process from Santiago de Chile', Revista Terrtitorios en Formación, (2) 7-20.

Borsdorf, A., Hidalgo, R. \& Sanchez, R. (2007), 'A New Model of Urban Development in Latin America: The Gated Communities and Fenced Cities in the Metropolitan Areas of Santiago de Chile and Valparaíso', Cities, 24(5): 365-78. https://doi.org/10.1016/j.cities.2007.04.002

Bowen, G.A. (2009), 'Document Analysis as a Qualitative Research Method', Qualitative Research Journal, 9(2): 27-40. https://doi.org/10.3316/QRJ0902027

Brain, I. \& Sabatini, F. (2006), 'Los precios del suelo en alza carcomen el subsidio habitacional, contribuyendo al deterioro en la calidad y localización de la vivienda social' [The increasing land prices erode the housing subsidy and deteriorate the quality and location of of the estate housing], Revista PROURBANA, 4: 2-13.

Brenner, N. \& Schmid, C. (2014), 'The "Urban Age" in Question', International Journal of Urban and Regional Research, 38(3), 731-55. https://doi.org/10.1111/1468-2427.12115

Brighenti, A.M. (2013), Urban Interstices: The Aesthetics and the Politics of the In-between (Farnham, Ashgate).

Burawoy, M. (1991), 'The Extended Case Method', in Ethnography Unbound. Power and Resistance in the Modern Metropolis (Los Angeles, CA, University of California Press), 271-90.

Cámara Chilena de la Construcción (2012), 'Disponibilidad de suelo en el gran Santiago' [Land availability in greater Santiago] Resultados Estudio 2012, Evolución 2007-2012.

Caspersen, O.H., Konijnendijk, C.C. \& Olafsson, A.S. (2006), 'Green Space Planning and Land Use: An Assessment of Urban Regional and Green Structure Planning in Greater Copenhagen', Geografisk Tidsskrift-Danish Journal of Geography, 106(2), 7-20. https://doi.org/10.1080/00167223.2006.10649553

Catalán, J., Fernandez, J. \& Olea, J. (2013), Cultivando Historia. Trayectorias, Problemáticas y Proyecciones de los Huertos de La Pintana (Santiago, Chile, Ed. Dhiyo).

Clichevsky, N. (2007), 'La tierra vacante "revisitada": elementos explicativos y potencialidades de utilización' [Vacant land revisited: explicative elements and land-use potentials], Cuaderno urbano: espacio, cultura y sociedad, (6): 195-219. https://doi.org/10.30972/crn.661023

Coq-Huelva, D. \& Asián-Chaves, R. (2019), 'Urban Sprawl and Sustainable Urban Policies. A Review of the Cases of Lima, Mexico City and Santiago de Chile', Sustainability, 11(20): 1-22. https://doi.org/10.3390/su11205835

Cox, T. \& Hurtubia, R. (2020), 'Subdividing the Sprawl: Endogenous Segmentation of Housing Submarkets in Expansion Areas of Santiago, Chile', Environment and Planning B: Urban Analytics and City Science, 48(7): 1770-86. https://doi.org/10.1177/2399808320947728

del Castillo, J.M. \& Sopla, P. (2018), 'Paisajes prehispánicos intersticiales: Naturaleza urbana y patrimonio arqueoastronómico en Ñaña, Lima' [Prehispanic interstitial landscapes: urban nature and archeo-astronomic patrimonia], Devenir-Revista de estudios sobre patrimonio edificado, 5(10): 153-74. https://doi.org/10.21754/devenir.v5i10.603

Duan, W., He, B., Nover, D., Fan, J., Yang, G., Chen, W., Fang, M.H. \& Liu, C. (2016), 'Floods and Associated Socioeconomic Damages in China over the Last Century', Natural Hazards, 82(1): 401-13. https://doi.org/10.1007/s11069-016-2207-2

Dubeaux, S. \& Sabot, E.C. (2018), 'Maximizing the Potential of Vacant Spaces Within Shrinking Cities, a German Approach', Cities, 75: 6-11. https://doi.org/10.1016/j.cities.2017.06.015

EMB Construccion Magazine (2016), 'Interview with Arturo Lyon. Proyecto Sur: Una respuesta diferencte frente al crecimiento urbano' [The South Project: A different response to urban growth], September 2016. at: http://www.emb.cl/construccion/articulo.mvc?xid=1814\&srch= parque $\% 20$ sur \&act $=4 \&$ tip $=\&$ xit $=[$ accessed Ocotber 2021$]$. 
Endres, D., Senda-Cook, S. \& Cozen, B. (2014), 'Not Just a Place to Park Your Car: Park(ing) as Spatial Argument', Argumentation and Advocacy, 50(3): 121-40. https://doi.org/10.1080/00028533.2014.11821814

Escobar, L. (2006), 'Indicadores sintéticos de calidad ambiental: un modelo general para grandes zonas urbanas' [Synthetic indicators of environmental quality; a model for large urban zones], EURE, 32(96): 73-98. https://doi.org/10.4067/S0250-71612006000200005

Evans, C. \& Lewis, J. (2018), Analysing Semi-structured Interviews Using Hematic Analysis: Exploring Voluntary Civic Participation Among Adults (London, SAGE). https://doi.org/10.4135/9781526439284

Flores, M., Otazo-Sánchez, E.M., Galeana-Pizaña, M., Roldán-Cruz, E.I., Razo-Zárate, R., GonzálezRamírez, C.A., Galindo-Castillo, E. \& Gordillo-Martínez, A.J. (2017), 'Urban Driving Forces and Megacity Expansion Threats. Study Case in the Mexico City Periphery', Habitat International, 64: 109-22. https://doi.org/10.1016/j.habitatint.2017.04.004

Flyvbjerg, B. (2006), 'Five Misunderstandings About Case-study Research', Qualitative Inquiry, 12(2): 219-45. https://doi.org/10.1177/1077800405284363

French, E.L., Birchall, S.J., Landman, K. \& Brown, R.D. (2019), 'Designing Public Open Space to Support Seismic Resilience: A Systematic Review', International Journal of Disaster Risk Reduction, 34: 1-10. https://doi.org/10.1016/j.ijdrr.2018.11.001

Gallent, N. \& Shaw, D. (2007), 'Spatial Planning, Area Action Plans and the Rural-Urban Fringe', Journal of Environmental Planning and Management, 50(5): 617-38. https://doi.org/10.1080/09640560701475188

Galletta, A. (2013), Mastering the Semi-structured Interview and Beyond: From Research Design to Analysis and Publication (New York, New York University Press). https://doi.org/10.18574/nyu/9780814732939.001.0001

Gandy, M. (2011), 'Interstitial Landscapes: Reflections on a Berlin Corner', in M. Gandy (ed.) Urban Constellations (Berlin, JOVIS), 149-52.

Gandy, M. (2013), 'Marginalia: Aesthetics, Ecology, and Urban Wastelands', Annals of the Association of American Geographers, 103(6): 1301-16. https://doi.org/10.1080/00045608.2013.832105

Gandy, M. (2016), 'Unintentional Landscapes', Landscape Research, 41(4): 433-40. https://doi.org/10.1080/01426397.2016.1156069

Gargiulo, C. \& Russo, L. (2017), 'Cities and Energy Consumption: A Critical Review', TeMA—Journal of Land Use, Mobility and Environment, 10(3): 259-78.

Gavin, H. (2008), 'Thematic Analysis', in Understanding Research Methods and Statistics in Psychology (London, SAGE), 273-81. .https://doi.org/10.4135/9781446214565.n17

Gavrilidis, A.A., Niță, M.R., Onose, D.A., Badiu, D.L. \& Năstase, I.I. (2019), 'Methodological Framework for Urban Sprawl Control Through Sustainable Planning of Urban Green Infrastructure', Ecological Indicators, 96: 67-78. https://doi.org/10.1016/j.ecolind.2017.10.054

Hare, M. \& Peña del Valle Isla, A. (2021), 'Urban Foraging, Resilience and Food Provisioning Services Provided by Edible Plants in Interstitial Urban Spaces in Mexico City', Local Environment, 26(7): 825-46. https://doi.org/10.1080/13549839.2021.1922998

Harrison, J. \& Heley, J. (2015), 'Governing Beyond the Metropolis: Placing the Rural in City-region Development', Urban Studies, 52(6): 1113-33. https://doi.org/10.1177/0042098014532853

Heinrichs, D. \& Nuissl, H. (2015), 'Suburbanisation in Latin America: Towards New Authoritarian Modes of Governance at the Urban Margin', in P. Hamel \& R. Keil (eds) Suburban Governance. A Global View (Toronto, University of Toronto Press), 216-38. https://doi.org/10.3138/9781442663565-014

Herzog, C.P. (2016), 'A Multifunctional Green Infrastructure Design to Protect and Improve Native Biodiversity in Rio de Janeiro', Landscape and Ecological Engineering, 12(1): 141-50. https://doi.org/10.1007/s11355-013-0233-8 
Hidalgo, R. (2007), ‘Se acabó el suelo en la gran ciudad? Las nuevas periferias metropolitanas de la vivienda social en Santiago de Chile' [Is the land over in the great city? The new metropolitan peripheries of state housing in Santiago de Chile], EURE, 33(98): 57-75.

https://doi.org/10.4067/S0250-71612007000100004

Hugo, J. \& du Plessis, C. (2020), 'A Quantitative Analysis of Interstitial Spaces to Improve Climate Change Resilience in Southern African Cities', Climate and Development, 12(7): 591-9. https://doi.org/10.1080/17565529.2019.1664379

Ige, J.O \& Atanda, T.A (2013), 'Urban Vacant Land and Spatial Chaos in Ogbomoso North Local Government, Oyo State, Nigeria', Global Journal of Human Social Science \& Environmental Science \& Disaster Management, 13(2): 28-36.

INE (Instituto Nacional de Estadisticas) (2017), 'Censo de Poblacion y Vivienda' [National Institute of Statistics, INE. Statistics of population and housing]. https://www.ine.cl/estadisticas/sociales/ censos-de-poblacion-y-vivienda/poblacion-y-vivienda [accessedJune 2021].

Inostroza, L., Baur, R. \& Csaplovics, E. (2013), 'Urban Sprawl and Fragmentation in Latin America: A Dynamic Quantification and Characterization of Spatial Patterns', Journal of Environmental Management, 115: 87-97. https://doi.org/10.1016/j.jenvman.2012.11.007

Iossifova, D. (2013), 'Searching for Common Ground: Urban Borderlands in a World of Borders and Boundaries', Cities, 34: 1-5. https://doi.org/10.1016/j.cities.2013.01.006

Jiang, Y., Zevenbergen, C. \& Ma, Y. (2018), 'Urban Pluvial Flooding and Stormwater Management: A Contemporary Review of China's Challenges and "Sponge Cities" Strategy', Environmental Science \& Policy, 80: 132-43. https://doi.org/10.1016/j.envsci.2017.11.016

Johnson, M.P. (2001), 'Environmental Impacts of Urban Sprawl: A Survey of the Literature and Proposed Research Agenda', Environment and Planning A, 33(4): 717-35. https://doi.org/10.1068/a3327

Jorgensen, A. \& Keenan, R. (2012), Urban Wildscapes (Abingdon, Routledge). https://doi.org/10.4324/9780203807545

Kaika, M. (2005), City of Flows: Modernity, Nature, and the City (Abingdon, Routledge). https://doi.org/10.4324/9780203826928

Keil, R. (2017), Suburban Planet: Making the World Urban from the Outside In (Cambridge, Polity).

Kiger, M.E. \& Varpio, L. (2020), 'Thematic Analysis of Qualitative Data: AMEE Guide No. 131', Medical Teacher, 42(8): 846-54. https://doi.org/10.1080/0142159X.2020.1755030

Kleerekoper, L., Van Esch, M. \& Salcedo, T.B. (2012), 'How to Make a City Climate-proof, Addressing the Urban Heat Island Effect', Resources, Conservation and Recycling, 64: 30-8. https://doi.org/10.1016/j.resconrec.2011.06.004

Koolhaas, R. (1995), 'Imagining the Nothingness', in R. Koolhaas \& B. Mau (eds) $S, X, L, X L$ (New York, The Monacelli Press).

Koolhaas, R. (2021), Countryside. A Report. The Countryside in your Pocket! (Cologne, Taschen).

Krellenberg, K., Müller, A., Schwarz, A., Höfer, R. \& Welz, J. (2013), 'Flood and Heat Hazards in the Metropolitan Region of Santiago de Chile and the Socio-economics of Exposure', Applied Geography, 38: 86-95. https://doi.org/10.1016/j.apgeog.2012.11.017

La Greca, P, La Rosa, D, Martinico, F. \& Privitera, R. (2011), 'Agricultural and Green Infrastructures: The Role of Non-urbanized Areas for Eco-sustainable Planning in a Metropolitan Region', Environmental Pollution, 159(1): 2193-202. https://doi.org/10.1016/j.envpol.2010.11.017

Li, Y., Shi, Y., Qureshi, S., Bruns, A. \& Zhu, X. (2014), 'Applying the Concept of Spatial Resilience to Socio-ecological Systems in the Urban Wetland Interface', Ecological Indicators, 42: 135-46. https://doi.org/10.1016/j.ecolind.2013.09.032

López-Morales, E. (2011), 'Gentrification by Ground Rent Dispossession: The Shadows Cast by Large-scale Urban Renewal in Santiago de Chile', International Journal of Urban and Regional Research, 35(2): 330-57. https://doi.org/10.1111/j.1468-2427.2010.00961.x 
López-Morales, E., Sanhueza, C., Espinoza, S., Ordenes, F. \& Orozco, H. (2019), 'Rent Gap Formation Due to Public Infrastructure and Planning Policies: An Analysis of Greater Santiago, Chile, 2008-2011', Environment and Planning A: Economy and Space, 51(7): 1536-57. https://doi.org/10.1177/0308518X19852639

Lu, Y., Xiao, Y. \& Ye, Y. (2017), 'Urban Density, Diversity and Design: Is More Always Better for Walking? A Study from Hong Kong', Preventive Medicine, 103: S99-S103. https://doi.org/10.1016/j.ypmed.2016.08.042

Mariani, M. \& Barron, P. (2013), Terrain Vague: Interstices at the Edge of the Pale (New York, Routledge).

McFarlane, C. (2012), 'Rethinking Informality: Politics, Crisis, and the City', Planning Theory \& Practice, 13(1): 89-108. https://doi.org/10.1080/14649357.2012.649951

Meijers, E.J. \& Burger, M. (2017), 'Stretching the Concept of "Borrowed Size”, Urban Studies, 54(1): 269-91. https://doi.org/10.1177/0042098015597642

Milián Bernal, D. (2020), 'Temporary Uses of Vacant and Abandoned Urban Spaces in Latin America: An Exploration. Built Environment and Architecture as a Resource', Lataukset, 29: 181-209.

MINVU (Ministerio de Vivienda y Urbanismo) (2014a), 'Towards a New Urban Policy for Chile: National Policy of Urban Development'. https://cndu.gob.c1/wp-content/uploads/2014/10/ L4-Politica-Nacional-Urbana.pdf [accessed March 2021].

MINVU (Ministerio de Vivienda y Urbanismo) (2014b), 'Texto Actualizado y Compaginado, Ordenanza Plan Regulador Metropolitano de Santiago (PRMS)' [Updated and compiled text of the Building Codes, Metropolitan Development Plan of Santiago]. http://metropolitana.minvu. cl/pag-m/documentacion-vigente-prms/ [accessed March 2021].

Moreno-Pessoa, I., Tasan-Kok, M.T. \& Korthals Altes, W.K. (2016), 'Brazilian Urban Porosity: Treat or Threat?', Proceedings of the ICE—Urban Design and Planning, 169(2): 47-55. https://doi.org/10.1680/udap.15.00009

ODEPA (2012), Análisis de los catastros sobre autorizaciones de cambio de uso de suelo de la región metropolitana de Santiago. Estudio de impacto de la expansión urbana sobre el sector agrícola en la región metropolitana de Santiago. [Analysis of land-use changes survey of the metropolitan región of Santiago. Study of imapct of urban expansión on agricultural land] (Santiago, Chile, Centro de Información de Recursos Naturales. Oficina de Estudios y Políticas Agrarias del Ministerio de Agricultura (ODEPA)).

Pessoa, I.M., Tasan-Kok, T. \& Altes, W.K. (2016), 'Brazilian Urban Porosity: Treat or Threat?', Proceedings of the Institution of Civil Engineers-Urban Design and Planning, 169(2): 47-55. https://doi.org/10.1680/udap.15.00009

Phelps, N. (2012), An Anatomy of Sprawl. Planning and Politics in Britain (Abingdon, Routledge).

Phelps, N.A. (2015), Sequel to Suburbia: Glimpses of America's Post-suburban Future (Cambridge, MA, MIT Press). https://doi.org/10.7551/mitpress/10407.001.0001

Phelps, N.A. (2021), 'Which City? Grounding Contemporary Urban Theory', Journal of Planning Literature, 36(3): 345-57. https://doi.org/10.1177/08854122211002758

Phelps, N.A. \& Silva, C. (2017), 'Mind the Gaps! A Research Agenda for Urban Interstices', Urban Studies, 55(6): 1203-22. https://doi.org/10.1177/0042098017732714

PLADECO (2011), Plan de Desarrollo Comunal de San Bernardo Bernardo [Communal Development Plan of San Bernardo], Secretaria Comunal de Planificación, SECPLA. I. Municipalidad de San Bernardo. Santiago, Chile.

Rayback, S. (2016), 'Making Observations and Measurements in the Field', in N. Clifford, M. Cope, S. French \& T. Gillespie (eds) Key Methods in Geography (London, SAGE), 325-35.

Rice, L. (2010), 'Retrofitting Suburbia: Is the Compact City Feasible?', Proceedings of the Institution of Civil Engineers-Urban Design and Planning, 163(4): 193-204. https://doi.org/10.1680/udap.2010.163.4.193 
Rickards, L., Gleeson, B., Boyle, M. \& O’Callaghan, C. (2016), 'Urban Studies After the Age of the City', Urban Studies, 53(8): 1523-41. https://doi.org/10.1177/0042098016640640

Romero, H. \& Órdenes, F. (2004), 'Emerging Urbanization in the Southern Andes. Environmental Impacts of Urban Sprawl in Santiago de Chile on the Andes Piedmont', Mountain Research and Development, 24(3): 197-201. https://doi.org/10.1659/0276-4741(2004)024[0197:EUITSA]2.0.CO;2

Roubelat, L. \& Armijo, G. (2012), 'Urban Agriculture in the Metropolitan Area of Santiago de Chile. An Environmental Instrument to Create a Sustainable Model', PLEA 2012-28th Conference, Opportunities, Limits \& Needs Towards an Environmentally Responsible Architecture, Lima, Perú 7-9 November.

Salet, W. \& Woltjer, J. (2009), 'New Concepts of Strategic Spatial Planning Dilemmas in the Dutch Randstad Region', International Journal of Public Sector Management, 22(3): 235-48. https://doi.org/10.1108/09513550910949217

Sandoval, V. \& Sarmiento, J. (2020), 'A Neglected Issue: Informal Settlements, Urban Development, and Disaster Risk Reduction in Latin America and the Caribbean', Disaster Prevention and Management, 29(5): 731-45. https://doi.org/10.1108/DPM-04-2020-0115

Santiago, C.M., Raggi, J.P.F. \& Erices, L.V. (2016), 'Urban Growth Trends in Midsize Chilean Cities: The Case of Temuco', Revista Brasileira de Gestão Urbana, 8(3): 375-89.

Saunders, J. (2011), 'Recreational and Ecological Politics in the In-between City: The Ongoing Development of Downsview Parks', in D. Young, P. Wood \& R. Keil (eds) In-between Infrastructure: Urban Connectivity in an Age of Vulnerability (Glasgow, Praxis), 237-49.

Savarda, J. Clergeaub, P. \& Mennechezb, G. (2000), 'Biodiversity Concepts and Urban Ecosystems', Landscape and Urban Planning, 48(3-4): 131-42. https://doi.org/10.1016/S0169-2046(00)00037-2

Scott, A.J. \& Storper, M. (2014), 'The Nature of Cities: The Scope and Limits of Urban Theory', International Journal of Urban and Regional Research, 39(1): 1-15. https://doi.org/10.1111/1468-2427.12134

Sieverts, T. (2003), Cities Without Cities. An Interpretation of the Zwischenstadt (London, Spon). https://doi.org/10.4324/9780203380581

Silva, C. (2019), 'The Interstitial Spaces of Urban Sprawl: Unpacking the Marginal Suburban Geography of Santiago de Chile', in N.H.D. Geraghty \& A.L. Massidda (eds) Creative Spaces: Urban Culture and Marginality in Latin America (London, Institute of Latin American Studies, University College London), 55-84.

Silva, C. (2020), 'The Rural Lands of Urban Sprawl: Institutional Changes and Suburban Rurality in Santiago de Chile', Asian Geographer, 37(2): 117-44. https://doi.org/10.1080/10225706.2019.1701505

Silva, C. \& Vergara, F. (2021), 'Determinants of Urban Sprawl in Latin-America: Evidence from Santiago de Chile', SN Social Sciences, 1(8): 1-35. https://doi.org/10.1007/s43545-021-00197-4

SINIA (2012), 'Diagnóstico de los suelos de la Región Metropolitana' [Analysis of Metropolitan Region's land], (Santiago, Chile, Servicio Nacional de Información Ambiental (SINIA), Centro de Documentación, Subsecretaría de Medio Ambiente).

Skidmore, M. (2014), 'Will a Greenbelt Help to Shrink Detroit's Wasteland', Land Lines, 26(4): 8-17.

Sola-Morales I. (1995), 'Terrain Vague', in C. Davidson Anyplace (Cambridge, MA, MIT Press), $118-123$.

Solá-Morales, I. (2002), Territorios (Barcelona, Editorial Gustavo Gili).

Sousa, R. (2009), 'Urban Landscape: Interstitial Spaces', Landscape Review, 13(1): 61-71.

Stender, M. (2017), 'Towards an Architectural Anthropology—What Architects Can Learn from Anthropology and Vice Versa', Architectural Theory Review, 21(1): 27-43. https://doi.org/10.1080/13264826.2016.1256333 
Storper, M. \& Scott, A. J. (2016), 'Current Debates in Urban Theory: A Critical Assessment', Urban Studies, 53(6): 1114-36. https://doi.org/10.1177/0042098016634002

Tadi, M., Zadeh, M., Biraghi, C. \& Brioschi, L. (2017), 'Urban Porosity. A Morphological Key Category for the Optimization of the CAS's Environmental and Energy Performance', GSTF Journal of Engineering Technology, 4(3): 138-46. https://doi.org/10.5176/2301-394X_ACE17.68

Tapia, R (2011), 'Social Housing in Santiago. Analysis of its Locational Behavior Between 1980-2002', INVI, 73(26): 105-31. https://doi.org/10.4067/S0718-83582011000300004

Tashakkori, A. \& Creswell, J.W. (2007), 'Exploring the Nature of Research Questions in Mixed Methods Research', Journal of Mixed Methods Research, 1(3): 207-11. https://doi.org/10.1177/1558689807302814

Tokman, A. (2006), 'El MINVU, la política habitacional y la expansión excesiva de Santiago', in A. Galetovic (ed.) Santiago: Dónde estamos y hacia dónde vamos [The MINVU, the housing policy and the excessive expansión of Santiago] (Santiago, Chile Centro de Estudios Públicos), 489-520.

Uehara, L., Button, C., Araújo, D., Renshaw, I. \& Davids, K. (2018), 'The Role of Informal, Unstructured Practice in Developing Football Expertise: The Case of Brazilian Pelada', Journal of Expertise, 1(3): 162-80.

Vásquez, A., Devoto, C., Giannotti, E. \& Velásquez, P. (2016), 'Green Infrastructure Systems Facing Fragmented Cities in Latin America-Case of Santiago, Chile', Procedia Engineering, 161: 1410-16. https://doi.org/10.1016/j.proeng.2016.08.602

Vásquez, A., Giannotti, E., Galdámez, E., Velásquez, P. \& Devoto, C. (2019), 'Green Infrastructure Planning to Tackle Climate Change in Latin American Cities', in Urban Climates in Latin America (Cham, Springer), 329-54. https://doi.org/10.1007/978-3-319-97013-4_13

Vidal, J.M.E. (2020), 'Gobernanza de la planificación territorial y el riesgo en Chile: El caso de San Bernardo y Calera de Tango', REDER, 4(2): 7-21.

Vidal, R. (2002), Fragmentation de la Ville et Nouveaux Modes de Composition Urbaine (Paris, L'Harmattan).

Viganò, P. (2013), 'Urbanism and Ecological Rationality', in S.T.A. Pickett, M.L. Cadenasso \& B. McGrath (eds) Resilience in Ecology and Urban Design. Linking Theory and Practice for Sustainable Cities (Dordrecht, Springer), 407-26. https://doi.org/10.1007/978-94-007-5341-9_25

Wall, E. (2011), 'Infrastructural Form, Interstitial Spaces and Informal Acts', in T. Hauck, R. Keller \& V. Kleinekert (eds) Infrastructural Urbanism: Addressing the In-between (Berlin, DOM Publishers), 145-57.

Wardekker, A., Wilk, B., Brown, V., Uittenbroek, C., Mees, H., Driessen, P., Wassen, M., Molenaar, A., Walda, J. \& Runhaar, H. (2020), 'A Diagnostic Tool for Supporting Policymaking on Urban Resilience', Cities, 101: 1-13. https://doi.org/10.1016/j.cities.2020.102691

Whitehand, J. (2001), 'British Urban Morphology: The Conzenian Tradition', Urban Morphology, 5: $103-9$.

Xie, Y., Gong, H., Lan, H. \& Zeng, S. (2018), 'Examining Shrinking City of Detroit in the Context of Socio-spatial Inequalities', Landscape and Urban Planning, 177: 350-61. https://doi.org/10.1016/j.landurbplan.2018.03.002

Yong, Y., Zhang, H., Wang, X.R. \& Schubert, U. (2010), 'Urban Land-use Zoning Based on Ecological Evaluation for Large Conurbations in Less Developed Regions: Case Study in Foshan, China', Journal of Urban Planning and Development, 136(2): 116-24. https://doi.org/10.1061/(ASCE)0733-9488(2010)136:2(116)

You, Q., Kang, S., Aguilar, E., Pepin, N., Flügel, W.A., Yan, Y., Xu, Y. Zhang, Y. \& Huang, J. (2011), 'Changes in Daily Climate Extremes in China and their Connection to the Large-scale Atmospheric Circulation During 1961-2003', Climate Dynamics, 36(11-12): 2399-417. https://doi.org/10.1007/s00382-009-0735-0 
Yuan, C. \& Ng, E. (2012), 'Building Porosity for Better Urban Ventilation in High-density CitiesA Computational Parametric Study', Building and Environment, 50: 176-89. https://doi.org/10.1016/j.buildenv.2011.10.023

Zegras, C. (2003), 'Financing Transport Infrastructure in Developing Country Cities: Evaluation of and Lessons from Nascent Use of Impact Fees in Santiago de Chile', Transportation Research Record: Journal of the Transportation Research Board, 1839: 81-8. https://doi.org/10.3141/1839-08

Zevenbergen, C., van Herk, S. \& Rijke, J. (2017), 'Future-proofing Flood Risk Management: Setting the Stage for an Integrative, Adaptive, and Synergistic Approach', Public Works Management \& Policy, 22(1): 49-54. https://doi.org/10.1177/1087724X16674473

Zhang, H. \& Grydehøj, A. (2021), 'Locating the Interstitial Island: Integration of Zhoushan Archipelago into the Yangtze River Delta Urban Agglomeration', Urban Studies, 58(10): 2157-73. https://doi.org/10.1177/0042098020937987

Živanović-Miljković, J., Crnčević, T. \& Marić, I. (2012), 'Land Use Planning for Sustainable Development of Peri-urban Zones', Spatium, 2012(28), 15-22. https://doi.org/10.2298/SPAT1228015Z

To cite the article: Cristian Silva (2021), 'Developing climate-responsive cities: exploring the environmental role of interstitial spaces of Santiago de Chile', Journal of the British Academy, 9(s9): 107-142.

DOI https://doi.org/10.5871/jba/009s9.107

Journal of the British Academy (ISSN 2052-7217) is published by The British Academy, 10-11 Carlton House Terrace, London, SW1Y 5AH www.thebritishacademy.ac.uk 